\title{
The evolution of the footwall to the Ronda subcontinental mantle peridotites: insights from the Nieves Unit (western Betic Cordillera)
}

\author{
S. MAZZOLI ${ }^{1}$, A. MARTÍN-ALGARRA², S. M. REDDY ${ }^{3}$, V. LÓPEZ SÁNCHEZ- \\ VIZCAÍNO $^{4}$, L. FEDELE $^{1} \&$ A. NOVIELLO ${ }^{1}$ \\ ${ }^{1}$ Dipartimento Scienze della Terra, Università di Napoli Federico II, Largo San \\ Marcellino 10, 80138 Naples, Italy \\ ${ }^{2}$ Departamento de Estratigrafía y Paleontología, Universidad de Granada, 18071 \\ Granada, Spain \\ ${ }^{3}$ The Institute for Geoscience Research \& ARC COE for Core to Crust Fluid Systems, \\ Department of Applied Geology, Curtin University of Technology, GPO Box U1987, \\ Perth WA 6845, Australia \\ ${ }^{4}$ Departamento de Geología (Unidad Asociada al IACT-CSIC, Granada), Escuela \\ Politécnica Superior de Linares, Universidad de Jaén, 23700 Linares, Spain \\ *Corresponding author (e-mail: stefano.mazzoli@unina.it) \\ 79778 characters of text (including spaces), 70 references, and 10 figures
}

Abbreviated title: Evolution of carbonates in the footwall of the Ronda peridotites

23

Abstract: Strongly heterogeneous deformation and extreme metamorphic gradients characterize the dominantly carbonate Nieves Unit in the footwall to the Ronda mantle extrusion wedge in the western Betic Cordillera. A well-developed foliation and mineral lineation, together with isoclinal intrafolial folds, occur in silicate-bearing, calcite/dolomite marbles within a $c .1,5 \mathrm{~km}$-thick metamorphic aureole underlying the peridotites. For the inferred maximum pressure of $300 \mathrm{MPa}$, petrological investigations allow to define temperature ranges for the main zones of the metamorphic aureole: forsterite zone $\left(>510{ }^{\circ} \mathrm{C}\right.$; probably c. $\left.700{ }^{\circ} \mathrm{C}\right)$, diopside zone $\left(510-430{ }^{\circ} \mathrm{C}\right)$, tremolite zone $\left(430-360{ }^{\circ} \mathrm{C}\right)$, and phlogopite zone $\left(360-330^{\circ} \mathrm{C}\right)$. Field structural analysis integrated with petrological, microstructural and EBSD textural data document large finite strains consistent with general shear within the metamorphic aureole, associated with NW-ward thrusting of the peridotites. On the other hand, post-kinematic silicate growth suggests that heat diffusion from the high-temperature peridotites continued after the final emplacement of the Ronda mantle extrusion wedge, leading to final zoning of the metamorphic aureole and to local partial annealing of calcite marble 
textures, particularly in the highest-temperature zone of the thermally softened footwall carbonates. Following substantial cooling, renewed crustal shortening affected the whole Nieves Unit, resulting in widespread development of NE-trending meso-scale folds.

In the western Betic Cordillera (Fig. 1), high-temperature tectonic emplacement of the Ronda mantle peridotites (Fig. 2) on top of crustal units (e.g. Lundeen, 1978) is marked by the occurrence of a 'metamorphic sole' in the footwall rocks (e.g. Tubía et al., 1997). In the southeastern, inner peridotite massif (Sierra Alpujata), a high pressuretemperature (P-T) shear zone records orogen-parallel (Tubía \& Cuevas, 1986; Orozco and Alonso-Chaves, 2012), sinistral shear between the peridotites and the Alpine eclogites of the Ojen Unit. In contrast, in the outer peridotite massif of Sierra Bermeja located to the NW (Fig. 2), a high-T dynamothermal metamorphic aureole records orogen-perpendicular, foreland-ward thrusting of the peridotites on top of both low-P metamorphic rocks of the Guadaiza Unit (Cuevas et al., 2006; Esteban et al., 2008) and sedimentary successions of the Nieves Unit (Mazzoli \& Martín-Algarra, 2011). These features have been interpreted in terms of deformation partitioning associated with oblique convergence during continental subduction and subsequent exhumation involving the coeval activity of kinematically linked systems of reverse, strike-slip and 'normal-sense' shear zones (Mazzoli \& Martín-Algarra, 2011). In this context, orogenparallel wrenching would have dominated the deeper, high-pressure portions of the continental subduction system, whereas orogen-perpendicular thrusting would have characterized the shallower, outer parts. Top-to-the-hinterland shear along the contact between the Ronda peridotites and overlying crustal rocks is consistent with extrusion of subcontinental mantle rocks of the overriding plate of the continental subduction system. Rapid exhumation of this extruding mantle wedge would have been further aided by strike-parallel extension and thinning of the crustal rocks overlying the peridotites (e.g. Tubía, 1994; Balanyà et al., 1997; Argles et al., 1999; Platt et al., 2003).

The crustal units lying in the footwall to the northwestern (i.e. outer) peridotite massif of Sierra Bermeja (Fig. 2) provide a unique opportunity to analyse strongly heterogeneous deformation associated with the 'hot' emplacement of a mantle wedge at shallow crustal levels. In the interior of the ultramafic massif, the contact at the base of the Ronda 
peridotites is exposed in the Guadaiza River tectonic window (Fig. 2). There, the contact is marked by a dynamothermal metamorphic aureole formed at the expense of footwall rocks (Cuevas et al., 2006; Esteban et al., 2008). High-T metamorphism is well constrained by $\mathrm{U} / \mathrm{Pb} \mathrm{SHRIMP}$ dating of zircons from thin, syn-kinematic leucogranite sheets that emanated from the aureole and intruded the overlying peridotites, which provided ages of $18.8 \pm 4.9 \mathrm{Ma}$ (Sánchez-Rodríguez \& Gebauer, 2000) and $21.8 \pm 0.5$ Ma (Esteban et al., 2007). The heat required for partial melting of footwall crustal rocks was provided by the fast emplacement of a $c .7 \mathrm{~km}$ thick, hot peridotite slab on top of the Guadaiza Unit, within the general framework of NW-directed overthrusting. This metamorphic aureole represents a low-viscosity, high-T $\left(>650{ }^{\circ} \mathrm{C}\right)$ shear zone characterized by a marked strain gradient towards the contact with the overlying ultramafic rocks (Esteban et al., 2008). On the other hand, the structure of footwall carbonate units occurring to the NW of the present leading edge of the Ronda mantle extrusion wedge has received much less consideration. The Nieves Unit rocks exposed in this area are characterized by a strong inverse metamorphic gradient (Martín-Algarra, 1987; Mazzoli \& Martín-Algarra, 2011). Within a c. $1.5 \mathrm{~km}$ thick zone, nonmetamorphic limestones/dolostones pass to high-grade marbles in contact with the overlying peridotites. The metamorphic gradient is marked by silicate minerals occurring in the marbles, defining a series of zones varying in thickness from tens to several hundred metres and characterized by the occurrence of (moving towards the peridotites; Figs. 3 and 4): (i) talc, (ii) phlogopite, (iii) tremolite, (iv) diopside, and (v) forsterite. Extreme deformation gradients and changes in structural styles accompany the metamorphic gradient and are the focus of this study, along with the texture of silicatebearing calcite marbles. Our results provide new insights into the metamorphic and deformation processes taking place in carbonate units adjacent to the Ronda high- $\mathrm{T}$ mantle wedge emplaced within the Betic orogen. In this (Behrmann, 1983) as well as in similar carbonate-rich orogenic belts such as the Alps (Pfiffner, 1982; Heitzmann, 1987; Burkhard, 1993) or the Apennines (Iannace et al., 2005, 2007; Vitale \& Mazzoli, 2005, 2009), marbles may record important deformation processes in the upper crust. Although naturally and experimentally deformed carbonates have been the subject of intense laboratory investigations aimed at a better understanding of the localization of plastic/superplastic flow in these rocks (e.g. Schmid et al., 1977, 1980, 1987; Rutter et al., 1994; Busch \& Van der Pluijm, 1995; Badertscher \& Burkhard, 2000; Bestmann et al., 2000; Pieri et al., 2001a, 2001b; Badertscher et al., 2002; Renner et al., 2002; Ulrich 
107 et al., 2002; Barnhoorn et al., 2004, 2005; Ebert et al. 2007a, b; Vitale et al., 2007), the

108 peculiar tectonic setting of the Nieves Unit allowed us analysing in detail the variation of 109 mesoscopic and microscopic structural features and of textural fabrics of impure 110 calcite/dolomite marbles for a range of temperature regimes - spanning over several 111 hundreds of degrees Celsius - within the km-thick dynamothermal metamorphic aureole 112 in the footwall to the Ronda peridotite mantle extrusion wedge.

\section{Geological Setting}

116 The Betic Cordillera, representing the westernmost part of the Alpine orogen in the 117 Mediterranean region, resulted from the convergence between the African and Iberian 118 plates since Late Cretaceous times (Andrieux et al., 1970; Durand-Delga \& Fontboté, 119 1980; Martín Algarra \& Vera, 2004). The Betic Cordillera, similarly to further Alpine 120 mountain belts in the Mediterranean area, is traditionally subdivided into Internal (i.e. 121 inner) and External (i.e. outer) Domains, with the Flysch Domain representing the 122 suture between the two (Fig. 1). The area of the present study forms part of the Internal 123 Domain of the western Betic Cordillera (Fig. 2). This domain is characterized by the 124 occurrence of low-angle extensional shear zones of regional extent, reworking the pre125 existing nappe structure (Balanyà et al., 1993; Argles et al., 1999). These extensional 126 contacts bound major allochthonous units characterized by varying tectonic and 127 metamorphic pre-Alpine and Alpine evolutions (Sánchez-Navas et al., 2012, and 128 references therein). The lower allochthon (Alpujarride Complex) records variable 129 Alpine P-T-t paths, generally characterized by high-pressure metamorphism followed 130 by decompression and final cooling at 18-16 Ma (Sánchez Rodríguez \& Gebauer, 2000). 131 The upper allochthon (Malaguide Complex) generally lacks Alpine metamorphism 132 (Martín-Algarra et al., 2009). A general lack of Alpine metamorphism characterizes 133 also the so-called 'Frontal Units' of the Internal Domain, one of which - i.e. the Nieves 134 Unit - is the subject of the present study; these units are thrust over the Flysch and 135 External Domains (Fig. 2). A series of unconformable marine basin successions 136 (Viñuela Group; Martín-Algarra, 1987) sit on top of the collapsed nappe pile.

137 Deposition of these Burdigalian clastic sediments predated backthrusting of the Flysch 138 Domain units above the Internal Domain (Fig. 2).

139 The Ronda peridotites form the lower portion of the traditionally recognized highest 140 Alpujarride nappe in the area. Above the mantle rocks, the highly attenuated Jubrique 
141 crustal section - including granulitic gneisses, migmatites, high-to-low grade pre142 Mesozoic metapelites, and Triassic metasediments at the top - is characterized by 143 isograds lying roughly parallel to the lithological contacts and to the regional foliation 144 (Balanyà et al., 1993, 1997; Tubía, 1994; Tubía et al., 1997). Although the Ronda 145 peridotites and the Jubrique crustal section are traditionally grouped into the so-called 146 Los Reales Nappe (Didon et al., 1973; Fig. 2), the contact between mantle and crustal 147 rocks consists of a high- $\mathrm{T}\left(\mathrm{T}=780^{\circ} \mathrm{C}\right)$ major shear zone responsible for partial 148 exhumation of the peridotites (van Wees et al., 1992; Balanyà et al., 1993; Van der Wal 149 \& Vissers, 1996; Argles et al., 1999) and representing the top of the mantle extrusion 150 wedge according to Mazzoli \& Martín-Algarra (2011). The Ronda peridotites are 151 mainly composed of plagioclase and spinel lherzolites (with subordinate garnet 152 lherzolites towards the top of the ultramafic body), mafic layers, and minor dunites and 153 harzburgites (Obata, 1980; Van der Wal \& Vissers, 1996; Garrido et al., 2011). They 154 form a series of massifs, the larger being those of Sierras Alpujata and Bermeja, where 155 ultramafic rocks are tectonically emplaced onto 'Blanca-type' Alpujarride units or onto 156 'Frontal Units' of the Internal Domain (Nieves Unit; Martín-Algarra, 1987; Fig. 2).

157 The 'Blanca-type' units (Ojen, Guadaiza, and Yunquera) share a typical Alpujarride 158 succession, with high-grade metapelites at the bottom, whose protoliths are of a 159 presumed Palaeozoic and Triassic age, and HT-marbles at the top, of probable Triassic, 160 and perhaps younger, sedimentary age (Hoeppener et al., 1963, 1964). Stratigraphic 161 data (Martín-Algarra \& Estévez, 1984; Martín-Algarra, 1987) and zircon geochronology 162 (Esteban et al., 2011) demonstrate the Early Miocene age (c. 20-22 Ma) of the high-T 163 Alpine metamorphism that affects all 'Blanca-type' units, which was related to their 164 tectonic emplacement below the Ronda peridotites. However, the Ojen Unit records a 165 first stage of high-P metamorphic conditions $\left(\mathrm{T}=790{ }^{\circ} \mathrm{C}, \mathrm{P} \geq 1.7 \mathrm{GPa}\right.$; Tubía \& Gil166 Ibarguchi, 1991) with a temperature peak dated at 19.9 $\pm 1.7 \mathrm{Ma}$ (Sánchez-Rodríguez \& 167 Gebauer, 2000) in eclogites derived from former Jurassic metabasites dated at $183 \pm 3$ 168 Ma. Fast exhumation (at a rate of $6 \mathrm{~km} \mathrm{Ma}^{-1}$; Orozco and Alonso-Chaves, 2012, and 169 references therein) of these high-P rocks, rather than by ultra-rapid extension and 170 extreme thinning of an unrealistic (> $50 \mathrm{~km}$ thick) nappe stack, is likely to have 171 occurred within a subduction channel (Mazzoli and Martín-Algarra, 2011). On the 172 contrary, the Guadaiza Unit displays exclusively evidence of low-P metamorphic 173 conditions $\left(\mathrm{T}=675-750{ }^{\circ} \mathrm{C}, \mathrm{P}=550-650 \mathrm{MPa}\right.$; Esteban et al., 2008). Finally, the 174 Yunquera Unit consists of an extremely thin, discontinuously exposed tectonic slice that 
175 was possibly produced by tectonic delamination of the Ojen Unit in the footwall to the 176 Ronda peridotite wedge, as it also preserves relics of high-P metamorphism (Martín177 Algarra, 1987). In the area of the present study, the Yunquera Unit is locally exposed in 178 the footwall to the Ronda peridotites (Fig. 3). Both of these units record NW-directed 179 thrusting over the Nieves Unit (Esteban et al., 2005; Mazzoli \& Martín-Algarra, 2011).

\section{The Nieves Unit}

182

183 The Nieves Unit (Dürr, 1967) is formed by a non-metamorphic - apart from the aureole 184 at the contact with the Ronda peridotites - Triassic to Lower Miocene sedimentary 185 succession (Fig. 4). A few tens of metres thick sole of strongly sheared, brown scaly 186 clays of the Campo de Gibraltar Complex, including frequent quatzarenites and rare micaceous sandstone phacoids, commonly occurs in its immediate footwall. This sole constitutes a strongly thinned and stretched tectonic mélange interposed between the Nieves Unit and the tectonically underlying Penibetic Units of the External Domain.

190 The hanging wall to the Nieves Unit is constituted by the Los Reales Nappe 191 (Alpujarride Complex), which in turn is overlain by the Malaguide Complex. Both 192 complexes thin rapidly northwards, forming a wedge-shaped, broad antiformal structure 193 whose core is occupied by the folded succession of the Nieves Unit (Fig. 4). The Ronda 194 peridotites at the base of the so-called Los Reales Nappe represent the thickest part of the wedge but rapidly disappear towards the $\mathrm{N}$ due to the hanging-wall cutoff above the

196 Nieves Unit (Fig. 4). The Jubrique crustal succession overlying the peridotites is mostly 197 eroded above the main outcrop of the Nieves Unit; however, thin remnants are 198 preserved as small klippen on top of the youngest beds of the Nieves succession (Nava 199 Breccia Fm., see below), being in turn locally overlain by klippen of Malaguide 200 Palaeozoic rocks (Fig. 3).

Stratigraphy

204 The stratigraphic succession of the Nieves Unit includes a c. $1.5 \mathrm{~km}$ thick Meso205 Cenozoic succession (Fig. 4) mainly made of carbonate formations showing typical 206 Alpine-Mediterranean facies.

207 The lowest formation is made of very thick- to medium-bedded Norian dolostones 208 showing shallow marine facies and a cumulative thickness in excess of $1 \mathrm{~km}$ (unit 1 in 
209 Fig. 4). Fine-grained terrigenous intercalations are locally present, especially in the 210 lowest part and towards the upper third part of the succession.

211 The top of the Triassic succession is made of up to $200 \mathrm{~m}$ thick, basinal, greyish and 212 locally yellowish marls alternating with hemipelagic micritic limestones (unit 2 in Fig. 4) 213 that gradually pass upwards (and laterally northwards) to black to dark-grey limestones 214 (unit 3 in Fig. 4). The Jurassic-Paleogene part of the succession (unit 4 in Fig. 4) starts 215 with cherty limestones (usually less than $200 \mathrm{~m}$ thick), locally including carbonate 216 turbidites rich in crinoidal bioclasts, mass-flow limestone breccias and red nodular 217 limestone horizons bearing lower Hettangian and Sinemurian ammonites. The 218 succession becomes marly towards the top of the Lower Jurassic section. Upwards, a 219 condensed pelagic succession develops (Martín-Algarra et al., 1998; O’Dogherty et al., 220 2001). It is made of Middle Jurassic red nodular and cherty limestones and radiolarian 221 cherts, Upper Jurassic and lowermost Cretaceous marly and cherty limestones with 222 ammonites, Saccocoma, Aptychus and Calpionella limestones (unit 5 in Fig. 4). The 223 latter are followed by varicoloured marls bearing Paleogene to Aquitanian planktonic 224 foraminifera and calcareous nannoplankton, with intercalated carbonate turbidites. The 225 succession of the Nieves Unit is topped by a Lower Miocene, rauhwacke-like, 226 continental carbonate breccia (Nava Breccia Fm; unit 6 in Fig. 4). This breccia is 227 cartographically unconformable onto the older formations of the Nieves Unit, although 228 being intensely folded together with the underlying part of the succession. The palaeogeographic and palaeotectonic significance of the Nava Breccia Fm 230 representing the youngest deposit involved in the deformation and, therefore, a key 231 stratigraphic unit of the study area - has been investigated by Martín-Algarra \& Estévez 232 (1984) and Martín-Algarra $(1987,2004)$ to which the interested reader is referred to.

233 Towards the SE, the sedimentary succession described above is overthrusted by the 234 Ronda peridotites (Fig. 5A), intensely deformed and transformed into a metamorphic 235 succession essentially made of both calcite and dolomite marbles, locally rich in quartz 236 lenses and levels, with subordinate intercalations of calcschists, calcareous metapelites 237 and paramphibolites (Figs. 5B-F and 6A-E). This transformation can be laterally 238 followed in the field, bed by bed, from non-metamorphic lithotypes to high-grade rocks 239 (see below), especially in the Torrecilla area (Fig. 2). 
243 The map-scale structure of the Nieves Unit is dominated by a NW-verging, overturned 244 syncline (Figs. 3 and 4) that can be traced for several tens of kilometres along strike 245 (Fig. 2). Regional folding around a gently NE-plunging axis (Fig. 7A) is well defined 246 also statistically by the distribution of the poles to bedding $\left(\mathrm{S}_{0}\right)$ and to the main 247 composite planar fabric $\left(\mathrm{S}_{0}-\mathrm{S}_{1}\right)$ measured from the metamorphic aureole (see below).

248 The stratigraphic succession, dominated by limestones and dolostones in the normal $249 \mathrm{limb}$ of the syncline, gives way to calcite/dolomite marbles in the overturned fold limb, 250 which is characterized by the previously mentioned dramatic metamorphic gradient. 251 Each stratigraphic unit mapped in the normal fold limb has a corresponding, well252 defined high-T equivalent in the metamorphic aureole of the overturned limb (Fig 4). 253 Here the original bedding, marked by clearly distinguishable lithological changes (Fig 254 5B), is generally parallel to a foliation, defining a composite $\left(\mathrm{S}_{0}-\mathrm{S}_{1}\right)$ planar fabric (Fig 255 5C-E). A dominantly SE-plunging (Fig. 7B) mineral lineation $\left(\mathrm{L}_{1}\right)$, defined by 256 elongated calcite/dolomite and locally tremolite crystals (Fig. 6A), occurs on the 257 composite $\left(\mathrm{S}_{0}-\mathrm{S}_{1}\right)$ planar fabric. Isoclinal intrafolial folds (Fig. 6B) display variably 258 plunging hinge lines (mainly tending to lie close to $\mathrm{L}_{1}$; Fig. 7C), and dominantly SSE 259 dipping axial surfaces (Fig. 7D). Field evidence for non-coaxial strain is rare; where 260 observed, it is represented by a sigmoidal foliation and S-C-C' structures indicating top261 to-the-NW sense of shear.

262 Minor NE-SW trending, open to close parasitic folds are associated with the regional 263 syncline in the non-metamorphic sedimentary succession of the Nieves Unit. They are 264 asymmetric (s-shaped looking towards NE) in the normal limb of the regional syncline 265 (Fig. 6D), and symmetric ( $m$-shaped) in its core (hinge region). An axial plane cleavage 266 - or weakly convergent cleavage in competent beds - is associated with these folds. 267 This foliation is intensely developed in the core of the regional syncline, particularly in 268 Jurassic-Paleogene units.

269 Open to tight, post-metamorphic folds deform the main composite planar fabric $\left(\mathrm{S}_{0}-\mathrm{S}_{1}\right)$ 270 in the metamorphosed overturned limb of the regional syncline (Fig. 6C), as well as 271 bedding $\left(\mathrm{S}_{0}\right)$ in its core and in the normal fold limb. These folds show NE-SW trending 272 hinge lines (Fig. 7E) and both SE- and NW-dipping axial surfaces (Fig. 7F). A variably 273 developed second-phase cleavage $\left(S_{2}\right)$ is associated with these folds, being axial-planar 274 to them in less competent lithologies and forming convergent cleavage fans in more 275 competent beds. The lack of neo-formed metamorphic minerals on $\mathrm{S}_{2}$ cleavage surfaces 276 suggests that this planar structure developed at very low-grade conditions. Within the 
metamorphic aureole, the intersection between $\mathrm{S}_{2}$ and the composite planar fabric $\left(\mathrm{S}_{0}-\mathrm{S}_{1}\right)$

278 defines a dominantly NE-trending linear structure parallel to the late fold hinges. A 279 similar NE-SW trend is also defined by calcite rods developed along buckled marblephyllite interfaces in the metamorphic units (the phyllites representing metamorphosed terrigenous intercalations in the carbonates).

282 The youngest shortening-related structures within the Nieves Unit include scattered 283 kink bands (Fig. 6E), whereas high-angle, dominantly extensional faults dissect all of 284 the previous structures as well as the main nappe contacts.

\section{Petrology and Microstructural Analysis: Materials and Methods}

In the following we describe the most representative mineral assemblages and textures of 25 selected silicate-bearing marbles sampled in the studied metamorphic aureole (Figs. 3 and 4). Rocks were sampled along the A-397 road (km 17 to 21), near the Cerro de los Cascajares peak, crossing the phlogopite, tremolite, diopside, and forsterite metamorphic zones defined by Martín-Algarra (1987), and in further outcrops, within the forsterite zone, close to the Cerro Alcojona peak (Table 1).

294 A first approximation to metamorphic conditions for the impure marbles of the Sierra de 295 las Nieves contact aureole was reached by means of appropriate petrogenetic grids. P-T 296 phase diagram projections (Fig. 9) were calculated using Perple X (Connolly, 1990, 2009 ) for the mixed-volatile $\mathrm{K}_{2} \mathrm{O}-\mathrm{CaO}-\mathrm{MgO}-\mathrm{Al}_{2} \mathrm{O}_{3}-\mathrm{SiO}_{2}-\mathrm{H}_{2} \mathrm{O}-\mathrm{CO}_{2}$ (KCMASHC) system, following the method by Connolly \& Trommsdorff (1991). Thermodynamic mineral data and the equation of state for $\mathrm{H}_{2} \mathrm{O}-\mathrm{CO}_{2}$ fluids were those of Holland \& Powell (1998, revised version 2002). The only solution model considered in the calculations was that of the $\mathrm{H}_{2} \mathrm{O}-\mathrm{CO}_{2}$ fluid (Trommsdorff \& Connolly, 1991). In the figures and following text, $\mathrm{F}$ represents the fluid composition expressed as $\mathrm{X}_{\mathrm{CO}_{2}}[=$ $\left.\mathrm{CO}_{2} /\left(\mathrm{CO}_{2}+\mathrm{H}_{2} \mathrm{O}\right)\right]$ and the numbers in parentheses are those of the pseudocompounds

304 (Connolly \& Kerrick, 1987) used by Perple X to represent fluid composition. All other phases were taken as pure phases and the following solid end-members were considered 306 (abbreviations after Whitney \& Evans, 2010): calcite (Cal), clinochlore (Clc), 307 clinohumite (Chu), diopside (Di), dolomite (Dol), forsterite (Fo), microcline (Mc), 308 phlogopite $(\mathrm{Phl})$, quartz (Qz), tremolite (Tr), and spinel (Spl).

309 This was a realistic simplification because most of the phases observed in the rocks

310 approach pure end-members compositions. In fact, $\mathrm{X}_{\mathrm{Mg}}[=\mathrm{Mg} /(\mathrm{Mg}+\mathrm{Fe})]$ in all 
311 ferromagnesian phases (amphibole, chlorite, clinohumite, clinopyroxene, olivine, and

312 spinel) commonly ranges between 0.90 and 0.95 (but in many cases it exceeds these

313 values) in the impure marble samples. Likewise, both calcite and dolomite display

314 compositions close to stoichiometry. Some exceptions are reported for phlogopite (with

315 up to 1.6 atoms per formula unit - a.p.f.u. - of total $\mathrm{Al} ; 11$ oxygens), chlorite (with up

316 to 2.6 a.p.f.u. of total $\mathrm{Al} ; 14$ oxygens) and clinohumite (very rich in fluorine: up to 1.7

317 a.p.f.u.; 13 cations). Pargasitic amphibole and clinopyroxene $\left(\mathrm{X}_{\mathrm{Mg}} \sim 0.60\right)$ occurring in

318 some pelitic intercalations also differ from the general trend, but these assemblages

319 were not taken into account in the calculations. Uncertainties associated with ignoring

320 these solid solutions are discussed below.

321 Electron backscatter diffraction (EBSD) data collected by scanning electron microscope

322 (SEM) were used for textural analysis of seven calcite marble samples and one dolomite

323 marble sample from the metamorphic aureole found in the overturned limb of the

324 regional syncline affecting the Nieves Unit. Samples 09A-1 and 09A-3 are from the

325 forsterite zone; sample 09A-7 is from the diopside zone; samples 09A-12, 09A-15, 09A-

32618 and 09A-19 are from the tremolite zone, and sample 09A-20 is from the phlogopite

327 zone. Thin sections of each sample were cut parallel to the mineral lineation (X) and

328 perpendicular to the composite planar fabric $\left(\mathrm{S}_{0}-\mathrm{S}_{1}=\mathrm{XY}\right.$; see below). Thin sections

329 were mechanically polished using down to $1 \mu \mathrm{m}$ diamond paste. To remove

330 mechanically-induced surface damage, a further 3 hours of polishing, with $0.06 \mu \mathrm{m}$

331 colloidal silica, was undertaken. Thin sections were coated with a thin layer of carbon to

332 prevent surface charging in the SEM. EBSD analysis was undertaken on a ZEISS-EVO

333 40XVP scanning electron microscope at Curtin University, Perth, Western Australia.

334 Collection, indexing and analysis of electron backscatter diffraction patterns (EBSP)

335 were carried out using the CHANNEL 5.10 software by Oxford Instruments. The EBSD

336 data were noise reduced using a 'wildspike' correction and a 7-neighbour zero solution

337 extrapolation following standard procedures (Reddy et al., 2007). Orientation data were

338 plotted with respect to the mesoscopic sample lineation and foliation ( $\mathrm{X}$ direction and

339 XY plane respectively), as lower hemisphere, equal area projections, using CHANNEL

340 Mambo software. Pole figure orientation data were plotted in terms of all of the

341 collected EBSD data ('all data') and as one point per grain data. For the latter, grain

342 boundaries were defined by misorientation boundaries in excess of $10^{\circ}$, and any twin

343 boundaries identified by a $78^{\circ}$ rotation around $<20-21>$ were ignored.

344 Finally, thin section microphotographs (acquired using a Leica DFC280 digital camera 
mounted on a Leitz Laborlux 12 Pol polarizing microscope) were employed for modal and carbonate grain size analyses of the same samples used for the textural analysis. Modal analyses were aimed to the quantification of the volume abundances of noncarbonate minerals (i.e. 'impurities', or secondary phases) and were performed using a point counting routine of the Leica QWinPlus V3.2.1 image analysis software. Carbonate grain size analyses were performed using the Image J 1.46r image analysis software (further details are summarized in Table 2).

\section{Petrology and Microstructural Analysis: Results}

Petrography of silicate-bearing marbles

The studied rocks consist of impure marbles containing relatively low amounts $(6.5 \%$ to $17.8 \%$ for the samples listed in Table 2) of non-carbonate minerals. Most of lower-T dolomite marbles can be defined as phlogopite-tremolite marbles with the significant local occurrence of chlorite or spinel (Table 1). They display a granoblastic texture with a rough foliation defined by the preferred orientation of fine grained aggregates of phlogopite, which may be also strongly folded (Figs. 8A-B). Phlogopite is also found as randomly oriented, small, isolated flakes and as randomly oriented, hypidioblastic larger flakes, commonly related to other silicates such as spinel and tremolite (e.g. sample 09A-11, Fig. 8D). Large, randomly oriented phlogopites may, however, display distinctive undulose extinction. Colourless amphibole is commonly associated with calcite grains or levels, and occurs as prismatic to acicular crystals rich in small dolomite inclusions. Amphibole grains are isolated (Fig. 8F) or give place to palmed aggregates, in many places with clear preferred orientation parallel to the main foliation (Fig. 8C). Chlorite (sample 09A-16; Table 1) appears as large hypidioblastic flakes having plenty of phlogopite and dolomite inclusions. Spinel (sample 09A-11; Table 1) is found as xeno- to hypidioblastic, isolated grains that grew after - or related to recrystallized phlogopite flakes (Fig. 8D).

374 Moving towards the peridotites, clinopyroxene is found in modal quartz-rich rocks 375 (with the exception of marble sample 09A-1; Table 1), usually consisting of pelitic or quartz-feldspar-bearing intercalations within the calcite marbles. Clinopyroxene appears as green pleochroic, isolated crystals or aggregates with largely variable grain size at the contact between quartz-rich and carbonate-rich levels (Fig. 8E). Highly birefringent 
scapolite poikiloblasts as well as minor amounts of alkali-feldspar, phlogopite and tremolite (Fig. 8E) also appear in some of these rocks, (that will not be taken into account in the phase diagram calculations below).

Within a few tens of metres to the peridotite, olivine-bearing calcite or calcite-dolomite marbles contain variable silicate assemblages and textures (Table 1). The most representative assemblages consist of $\mathrm{Cal}+\mathrm{Dol}+\mathrm{Phl}+\mathrm{Amp}+\mathrm{Ol} \pm \mathrm{Chu} \pm \mathrm{Spl}$ (abbreviations after Whitney \& Evans, 2010), while clinopyroxene and chlorite have been found only in one sample within this zone. Silicate minerals typically display textural characteristics indicative of static growth post-dating deformation (e.g. large grain size, lack of preferred orientation, hypidioblastic shape; Fig. 8F). In further instances silicates occur as non-deformed aggregates of mostly xenoblastic grains with complex interrelationships reflecting metamorphic reactions (Fig. 8G). This is also indicated by the occurrence of late poikiloblasts of dolomite surrounding these aggregates.

393 In tremolite and higher-T mineral zones, centimetre-scale phlogopite-tremolite clots that

394 clearly displaced and overgrew the main composite planar fabric $\left(\mathrm{S}_{0}-\mathrm{S}_{1}\right)$ are observed also in outcrop (Fig. 5F). However, as mentioned previously, tremolite crystals also

Metamorphic analysis

A simplified petrogenetic grid for the KCMASHC system and a wide P-T range is shown in Fig. 9 (A). Both fluid-present and fluid-absent univariant equilibria occur. The most striking feature of this P-T projection is that most of the curves display very steep and remarkably constant Clapeyron slopes, thus defining narrow zones in which the stability of phase assemblages is strongly dependent on temperature and fluid composition (e.g. Fig. 9B). Calculations for the $\mathrm{K}_{2} \mathrm{O}-\mathrm{CaO}-\mathrm{FeO}-\mathrm{MgO}-\mathrm{Al}_{2} \mathrm{O}_{3}-\mathrm{SiO}_{2}-\mathrm{H}_{2} \mathrm{O}-$ $\mathrm{CO}_{2}$ system (KCFMASHC) that take into account the limited Fe-Mg solid solution $\left(\mathrm{X}_{\mathrm{Mg}}\right.$ usually $<0.95)$ in the ferromagnesian minerals reveals a negligible shift towards higher temperatures of the reactions of interest (not shown in the figures) and will not be considered in the following. The effect of the solid solutions models for phlogopite

410 (between the phlogopite-eastonite end-members) and chlorite (between the clinochlore-

411 amesite end-members), applying for the Al amounts observed in these minerals, has 412 also been tested. As a general trend, for the reactions of interest, pseudounivariant 
curves with Al-richer pseudocompounds shift toward higher temperatures. However,

414 within the range of the limited solid solutions observed in the studied minerals, this is a

415 minor effect when compared with that of the changing fluid phase composition and will

416 not be further considered. As a result, in the following analysis univariant reactions with

417 steep Clapeyron slopes (especially those involving phlogopite or chlorite) should be

418 regarded as indicators of the minimum temperature conditions at which observed

419 minerals or assemblages were stable. In contrast with these steep reactions, only a few

420 reactions display gentle or variable Clapeyron slopes. Among these, the reaction Cal +

$421 \mathrm{Tr}+\mathrm{Fo}=\mathrm{H}_{2} \mathrm{O}+\mathrm{Di}+$ Dol sets the highest pressure limit for the observed mineral

422 assemblage, in which calcite, amphibole and olivine coexist. Accordingly, all further P-

$423 \mathrm{~T}$ projections (Fig. 9B to D) correspond to the expanded field between 50 and $500 \mathrm{MPa}$,

424 and between 300 and $700{ }^{\circ} \mathrm{C}$ for the same KCMASHC system. This pressure range is

425 consistent with the previously described geological setting of the contact aureole. Based

426 on geological evidence pointing to a burial depth of c. $10 \mathrm{~km}$ (including the mantle

427 peridotites; Mazzoli \& Martín-Algarra, 2011), maximum pressures may be further

428 constrained to around $300 \mathrm{MPa}$. These $\mathrm{P}$ conditions are roughly similar to those

429 suggested by Esteban et al. (2008) for the Guadaiza River tectonic window just south of

430 our study area (Fig. 2).

431 Metamorphic conditions for the occurrence of phlogopite, amphibole, spinel and

432 chlorite in the studied aureole can be discussed from selected representative equilibria 433 shown in Fig. 9 (B) and summarized in Fig. 9 (D). Minimum temperature conditions for

434 the first occurrence of phlogopite in the dolomite-bearing rocks are controlled by the 435 univariant reaction indicating the breakdown of detrital microcline (e.g. Rice, 1977) in 436 the presence of water-rich fluid: $\mathrm{F}\left(\mathrm{H}_{2} \mathrm{O}\right)+\mathrm{Dol}+\mathrm{Mc}=\mathrm{F}(\mathrm{CO} 6.6)+\mathrm{Cal}+\mathrm{Phl}$. 437 Depending on the latter parameter, the Phl-in reaction turns to be projected as 438 pseudounivariant equilibria (Connolly \& Trommsdorff, 1991), represented as grey thin 439 dashed curves, in which only one (that of coexisting 6.6 and 9.9 pseudocompounds) is 440 labelled with the complete reaction and all the remaining ones are labelled with the 441 mean value of coexisting pseudocompounds (Fig. 9B). As a result, it can be deduced 442 that the first appearance of phlogopite can take place in a wide divariant field with 443 increasing temperature conditions for $\mathrm{CO}_{2}$-richer fluids. For the estimated maximum 444 pressure of $300 \mathrm{MPa}$ (thick grey dashed line in Fig. 9D), the minimum temperature for 445 the stability of phlogopite is $350^{\circ} \mathrm{C}$. 
446 A similar analysis can be carried out for defining the tremolite-in conditions. In 447 dolomite and quartz-bearing marbles, this takes place due to the univariant reaction: $448 \mathrm{~F}\left(\mathrm{H}_{2} \mathrm{O}\right)+\mathrm{Qz}+\mathrm{Dol}=\mathrm{F}(\mathrm{CO6} .6)+\mathrm{Cal}+\mathrm{Tr}$. The divariant field defined by 449 pseudounivariant equilibria (only that corresponding to pseudocompounds 16.4 and 45019.7 is represented with a thin black dashed curve) is shaded in light grey in Fig. 9 (B). 451 In pure calcite marbles the univariant tremolite-in reaction is: $\mathrm{F}\left(\mathrm{H}_{2} \mathrm{O}\right)+\mathrm{Qz}+\mathrm{Cal}+\mathrm{Phl}$ $452=\mathrm{F}(\mathrm{CO} 6.6)+\mathrm{Tr}+\mathrm{Mc}$; sample pseudounivariant equilibrium with pseudocompounds $453 \quad 13.1$ and 16.4 is represented with a thin continuous black curve and the divariant field is 454 shaded in darker grey in Fig. 9 (B). Thus, at $300 \mathrm{MPa}$, the minimum temperature for the 455 appearance of tremolite ranges from $360{ }^{\circ} \mathrm{C}$ in quartz-bearing dolomite marbles to 410 $456{ }^{\circ} \mathrm{C}$ in calcite marbles (Fig. 9D). In the studied selected samples the latter rock type is 457 more abundant than the former one (cf., Table 1).

458 The first appearance of spinel in the petrogenetic grids of Fig. 9 (B, D) is indicated by 459 the fluid-absent univariant reaction: $\mathrm{Tr}+\mathrm{Dol}+\mathrm{Mc}+\mathrm{Clc}=\mathrm{Cal}+\mathrm{Phl}+\mathrm{Spl}+\mathrm{Qz}$ at an 460 almost constant temperature of $430{ }^{\circ} \mathrm{C}$. At higher $\mathrm{T}\left(500{ }^{\circ} \mathrm{C}\right.$ at $\left.300 \mathrm{MPa}\right)$, the reaction $461 \mathrm{Dol}+\mathrm{Mc}+\mathrm{Clc}=\mathrm{Cal}+\mathrm{Phl}+\mathrm{Spl}+\mathrm{Qz}+\mathrm{F}$ takes place. Both are clinochlore 462 breakdown reactions yielding the same solid products. The coexistence of $\mathrm{Cal}, \mathrm{Phl}$ and 463 Spl is well documented (e.g. Fig. 8D), whereas Qz is always lacking. This can be easily 464 explained taking into account that the chlorite end-member phase employed in the 465 calculations (clinochlore) is richer in $\mathrm{Si}$ than real chlorites observed in the rocks (3 $\mathrm{Si}$ 466 a.p.f.u. versus $2.5 \mathrm{Si}$ a.p.f.u.). Irrespective of composition, chlorite is stable in the 467 KCMASHC system, at Al-rich compositions, in the whole considered P-T range.

468 Selected relevant equilibria explaining the occurrence of diopside, olivine, and 469 clinohumite are displayed in Fig. 9 (C). Observed diopside-bearing rocks are lacking in 470 dolomite and very rich in quartz (Table 1). The first appearance of diopside in calcite 471 marbles takes place through the univariant reaction: $\mathrm{F}\left(\mathrm{H}_{2} \mathrm{O}\right)+\mathrm{Qz}+\mathrm{Cal}+\mathrm{Tr}=\mathrm{Di}+$ $472 \mathrm{~F}(\mathrm{CO} 6.6)$. As in the previous cases, a divariant field (dark grey shading) towards higher 473 temperatures is defined by pseudounivariant reactions with increasing $\mathrm{X}_{\mathrm{CO}_{2}}$ in the fluid 474 composition (reaching up to 0.58 ). The described Di-Cal-Qz divariant field (dark grey; 475 Fig. 9D) partially overlaps with that of the tremolite-in conditions (light grey). At 300 $476 \mathrm{MPa}$, the minimum temperature of this divariant field exactly fits that of the first Spl-in 477 reaction $\left(430^{\circ} \mathrm{C}\right)$. Taking into account that the sample with the product assemblage of 478 this reaction (09A-11; Table 1) is located only about $200 \mathrm{~m}$ away from the first 
appearance of diopside, it could be suggested that $\mathrm{Di}$-in temperatures must be somewhat 480 higher than those of Spl-in (Fig. 9D).

481 Concerning forsterite stability, first P-T constraints are defined by equilibrium Cal $+\mathrm{Tr}$ $482+\mathrm{Fo}=\mathrm{F}+\mathrm{Dol}+\mathrm{Di}$, with a strongly changing Clapeyron slope and increasing $\mathrm{X}_{\mathrm{CO}_{2}}$ 483 composition of fluid with decreasing pressure (number labels of pseudoinvariant points 484 along the curve; Fig. 9D). This curve constrains the stability of the assemblage $485 \mathrm{Cal}+\mathrm{Tr}+\mathrm{Fo}$, observed in most rocks close to the contact with the peridotites (Table 1), to 486 maximum values of $\mathrm{P}=500 \mathrm{MPa}$ (at $300^{\circ} \mathrm{C}$ ) and $\mathrm{T}=575^{\circ} \mathrm{C}$ (at $200 \mathrm{MPa}$ ). Within this 487 field, the minimum temperature is further constrained by the reaction $\mathrm{F}\left(\mathrm{H}_{2} \mathrm{O}\right)+\mathrm{Tr}+$ 488 Dol $=\mathrm{F}(\mathrm{CO} 6.6)+\mathrm{Cal}+\mathrm{Fo}$ and its related divariant field with coexisting Tr, Dol, Cal 489 and Fo and variable fluid composition (thin, grey, dashed pseudounivariant curves; Fig. 490 9C). At $300 \mathrm{MPa}$ this field ranges from 510 to $560{ }^{\circ} \mathrm{C}$ and partially overlaps with the 491 field of minimum temperatures for Di-in (Fig. 9D). This is consistent with the mineral 492 assemblage observed in rocks (sample 09A-1; Table 1) sampled close to the contact 493 with the peridotites. Additional information can be obtained from both chlorite and 494 clinohumite. The former has been observed at least in one Fo and Spl-bearing sample 495 (09A-4; Table 1). Both reactions $\mathrm{Clc}+\mathrm{Chu}=\mathrm{H}_{2} \mathrm{O}+\mathrm{Fo}+\mathrm{Spl}$ and $\mathrm{F}\left(\mathrm{H}_{2} \mathrm{O}\right)+\mathrm{Dol}+\mathrm{Clc}$ $496=\mathrm{F}(\mathrm{CO} 6.6)+\mathrm{Cal}+\mathrm{Spl}+\mathrm{Fo}$ are chlorite-breakdown reactions producing coexisting $\mathrm{Fo}_{\mathrm{O}}$ 497 and Spl, consistent with the observed rock assemblages (Table 1, Fig. 8G), and 498 indicating minimum temperature conditions ranging from 525 to $600{ }^{\circ} \mathrm{C}$ at $300 \mathrm{MPa}$ 499 (Fig. 9D). Equilibria indicating the observed coexistence of clinohumite and olivine 500 (Table 1, Fig. 8G) are the already mentioned $\mathrm{Clc}+\mathrm{Chu}=\mathrm{H}_{2} \mathrm{O}+\mathrm{Fo}+\mathrm{Spl}$, and also $\mathrm{H}_{2} \mathrm{O}$ $501+\mathrm{Dol}+\mathrm{Fo}=\mathrm{Cal}+\mathrm{Chu}+\mathrm{F}(\mathrm{CO} 6.6)$. The stability of clinohumite increases towards 502 higher temperatures with increasing fluorine contents (Rice, 1980). Taking this into 503 account and attending to petrogenetic grids in Fig. 9 (A to C), it could be suggested that 504 clinohumite-bearing assemblages sampled close to the contact with the peridotites 505 might have reached maximum temperatures above $700{ }^{\circ} \mathrm{C}$.

506 In conclusion, phase relations modelling in the KCMASHC system suggest the 507 following approximate temperature ranges for the observed metamorphic zones of the 508 Nieves Unit contact aureole at the maximum, geologically consistent, pressure of 300 $509 \mathrm{MPa}$ (Fig. 9D): forsterite $\left(>510^{\circ} \mathrm{C}\right.$; probably around $\left.700{ }^{\circ} \mathrm{C}\right)$, diopside $\left(510-430{ }^{\circ} \mathrm{C}\right)$, 510 tremolite $\left(430-360^{\circ} \mathrm{C}\right)$, phlogopite $\left(360-330^{\circ} \mathrm{C}\right)$.

512 Microstructural Analysis 
514 Calcite (dolomite poor) marbles occur as strongly deformed rocks, displaying a variety 515 of conspicuous microstructures in calcite grains (Fig. 8A, F): elongated grains defining 516 a main foliation, curved twins, undulose extinction or mortar textures. The presence of 517 subgrains and new recrystallized grains is common. Irregular (lobate) grain boundaries 518 are also observed, pointing to the occurrence of grain boundary migration 519 recrystallization. Dolomite-bearing marbles, on the contrary, commonly show a 520 granoblastic texture (Fig. 8B).

521 Besides a general - though irregular - trend of calcite grain size increase from lower to 522 higher metamorphic grades (Table 2), a variation of marble microstructures with 523 distance from the peridotites (and hence temperature) is observed. The more distant 524 calcite marbles (phlogopite and tremolite zones) tend to preserve deformation features, 525 such as S-C-C' structures, recording top-to-NW shearing (Fig. 8J) that are not observed 526 in the strongly recrystallized high-T marbles from the diopside and forsterite zones. A 527 secondary foliation, oblique with respect to the main composite $\left(\mathrm{S}_{0}-\mathrm{S}_{1}\right)$ foliation and 528 produced by grain boundary alignment of recrystallized grains, is observed in samples 529 from the tremolite through the forsterite zones (Fig. 8K, H). All of these samples show 530 evidences of dynamic recrystallization resulting from a combination of both subgrain 531 rotation and grain boundary migration. However, marbles from the forsterite zone also 532 show straight grain boundaries and calcite triple junctions that are indicative of variable 533 degrees of static recrystallization (Fig. 8H, I). The latter process appears to have led in 534 some cases to a partially annealed microstructure characterized by generally equant, 535 polygonal calcite grains (Fig. 8I). However, in one of the forsterite zone samples (09A536 1), finer-grained zones of recrystallized grains cut across the annealed, coarse-grained 537 microstructural domains.

538 For samples from the diopside through the tremolite to the phlogopite zones (09A-7 to 539 09A-20), plots of all orientation data are very similar to the plots of 1 point per grain.

540 This similarity reflects the equigranular nature of these samples. In contrast, orientation 541 data from 09A-1 and 09A-3 (forsterite zone) show a significant difference between plots 542 of all of the collected EBSD data (not shown) and 1 point per grain data because of the 543 heterogeneous grain size and of the grain size bias associated with the larger grains. For 544 forsterite zone samples we therefore only considered the one point per grain data.

545 EBSD data from the different metamorphic zones of the carbonate footwall show a 546 number of similarities. In most cases (Fig. 10), the pole figures record a crystallographic 
547 preferred orientation (CPO) with alignment of the calcite $c$-axis with the pole to the main

$548 \mathrm{~S}_{0}-\mathrm{S}_{1}$ foliation $(\mathrm{Z})$. This is most strongly pronounced in samples 09A-7 and 09A-20. In

549 09A-1 the single $c$-axis cluster lies oblique to $\mathrm{Z}$ and is rotated in the direction of the 550 macroscopically established top-to-NW sense of shear. In other samples a subordinate 551 component of the $c$-axis orientation also lies oblique to the $\mathrm{Z}$ direction, again synthetic 552 with respect to the direction of the macroscopically established top-to-NW sense of 553 shear (Fig. 10). The angular relationships between the different concentrations on the $c$ 554 axis pole figure (usually $<40^{\circ}$ ) are not consistent with these clusters being associated 555 with twinning in the samples. Comparison with high strain calcite deformation 556 experiments indicates that such a pattern in $c$-axis orientations is consistent with high 557 shear strains (Barnhoorn et al., 2004) with varying degrees of recrystallization (Pieri et 558 al., 2001a). Only in 09A-19, there is a less defined and more symmetric distribution of $559 \quad c$-axes (Fig. 10). This sample retains evidence for non-coaxial deformation in the form 560 of well-developed S-C fabrics with C-planes dominated by fibrous tremolite (Fig. 8J) 561 but again there is no significant asymmetry within the (0001) pole figure data. Along 562 with all other samples no variation in $+<\mathrm{a}>$ and $-<\mathrm{a}>$ was observed (Fig. 10). This 563 contrasts observation on non-coaxially deformed calcite marble where asymmetry in $564+<\mathrm{a}>$ and $-<\mathrm{a}>$ are recorded during both low- and high-T non-coaxial flow (Bestmann, 565 2000; Pieri et al., 2001b) and may reflect a strong component of high-temperature 566 recrystallization and steady-state flow (Pieri et al., 2001a), and/or a component of static 567 recrystallization (Barnhoorn et al., 2005) that is consistent with the microstructure observed in high-T marbles. The data presented here indicate that orthorhombic symmetry of fabrics with respect to the principal $\left(\mathrm{S}_{0}-\mathrm{S}_{1}\right)$ foliation plane cannot be used to provide unambiguous constraints on the coaxial or non-coaxial nature of the deformation at high temperature and high-strain rate conditions. However, where asymmetry in the $c$-axis distribution relative to the foliation is recorded, then this appears to be synthetic with respect to the rotational component of the non-coaxial strain inferred from S-C fabrics and mesoscopic kinematic criteria.

575 Misorientation axes for calcite marble data record differences between samples. In 576 samples where significant low-angle boundaries are preserved (09A-1, 09A-7, and 09A20) there is a dominant misorientation axis concentration associated with the ' $a$ ' $<11$ $20>$ direction. This direction is still common in 09A-3 and 09A-19 which also have a significant number of measurements $(n>1000)$, but other orientations are also apparent associated with ' $\mathrm{f}$ ' $<02-21>$, ' $\mathrm{m}$ ' $<10-10>$. In samples where low-angle boundaries are 
rare (09A-12 and 09A-18), misorientation axes are concentrated close to the $<0001>$

582 direction. The observed variation in the misorientation axes reflects the operation of

583 different slip systems in calcite with $<11-20>$ corresponding to the common high temperature $\left(>400{ }^{\circ} \mathrm{C}\right)$ slip systems $\mathrm{r}\{10-14\}<-2021>$ and $\mathrm{f}\{-1012\}<10-11>$, whilst ' $\mathrm{m}$ ' $<10-10>$ is consistent with deformation by $\{0001\}<-12-10>$ slip (De Bresser \& Spiers, 1997). In some of the samples (09A-1, 09A-18, 09A-19), misorientation axis evidence for the operation of $\mathrm{f}\{-1012\}<0-2-21>$ is consistent with low temperature deformation (De Bresser \& Spiers, 1997) and this may reflect a lower temperature overprint that may also have been responsible for the localized zones of reduced grain size observed in the highest temperature sample (09A-1). Such a lower temperature overprint could have led to a finer grain size of samples 09A-18 and 09A-19 (Table 2) as a result of dynamic recrystallization dominated by subgrain rotation.

EBSD analysis has also been performed on a dolomite marble sample (09A-15) from the tremolite zone (Fig. 10). The CPO in this sample, although clearly marked by the $c$-axis distribution, is weaker than that generally recorded by calcite marbles and also shows different misorientation axes from most of the calcite-dominated samples. This contrast suggests the operation of a different set of slip systems, albeit including the common $(0001)<2-1-10>$ slip system (Wenk, 1985). The asymmetry of the $c$-axis distribution with respect to the $S_{0}-S_{1}$ foliation plane is synthetic with the rotational component of simple shear.

601

602

Discussion

603

604 The Nieves Unit is characterized by significant changes in styles and intensity of 605 deformation, with strongly heterogeneous structural development being closely linked 606 to an inverse metamorphic gradient that is controlled by distance from the hanging-wall 607 Ronda peridotites. This variation is expressed by different deformation features at 608 different structural position within the main regional syncline involving the studied unit. 609 This major structure may be interpreted as a result of footwall deformation within the 610 general framework of bulk non-coaxial strain associated with top-to-the-NW shearing.

611 The normal limb and core region of the regional syncline are characterized by the 612 occurrence of NE-SW trending, meso-scale parasitic folds, whereas in the metamorphic 613 aureole of the inverted limb, isoclinal, intrafolial folds occur. The hinge lines of these 614 latter folds tend to lie close to the stretching direction and are interpreted to have been 
615 strongly rotated towards this direction during progressive deformation. The occurrence

616 of a well-developed foliation and associated mineral lineation, together with isoclinal

617 intrafolial folds in the marbles, indicates that these rocks record a significant amount of

618 finite strain, although shear-sense indicators are rarely observed in the field. These

619 features are consistent with progressive strain localisation in the inverted limb of the

620 major syncline. As a matter of fact, the overturned fold limb of the regional syncline

621 appears to constitute a SE dipping, thermally softened carbonate rock panel that

622 underwent intense deformation and metamorphism associated with the emplacement of

623 the Ronda peridotites.

624 Both field and thin section evidence indicate a limited syn-kinematic growth of silicate

625 minerals (locally testified by the preferred orientation of early generations of tremolite 626 and phlogopite, Fig. 8B, C). However, most silicate grain growth appears to have 627 occurred statically, following the development of the composite planar fabric $\left(\mathrm{S}_{0}-\mathrm{S}_{1}\right)$ and 628 mainly post-dating the main internal deformation in the marbles (Fig. 8F). This suggests 629 that high-T footwall deformation associated with peridotite emplacement occurred at a 630 much faster rate with respect to heat diffusion, which continued well after peridotite 631 emplacement. Estimated maximum temperatures in the metamorphic aureole range from 632 values in excess of $510{ }^{\circ} \mathrm{C}$ (probably around $700{ }^{\circ} \mathrm{C}$ ) close to the contact with the 633 peridotites to $<350^{\circ} \mathrm{C}$ in the more distant, less thermally overprinted rocks, for the 634 inferred maximum pressure of $300 \mathrm{MPa}$. Higher-pressure values are rather unlikely due 635 to the complete lack of regional metamorphism of the Nieves Unit away from the 636 aureole at the contact with the peridotites. Had the overlying tectonic units been 637 significantly thicker than c. $10 \mathrm{~km}$, the whole footwall (Nieves Unit) would have 638 undergone greenschist facies metamorphism (which is not observed). Therefore, it can 639 be realistically considered that the present-day geometry (taking erosion into account; 640 see geological sections in Figs. 2 and 4) is representative of the original (Miocene) 641 tectonic load on top of the Nieves Unit (Mazzoli and Martín-Algarra, 2011, their fig. 6). 642 This is consistent with syn-orogenic extension (Argles et al., 1999) of the Jubrique 643 crustal rocks originally overlying the Ronda peridotites. The crustal succession was 644 being tectonically attenuated as the Ronda peridotites were exhuming, so that the Los 645 Reales Unit was already significantly thinned (essentially to its present-day thickness) 646 when final emplacement on top of the Nieves Unit occurred (Mazzoli and Martín647 Algarra, 2011, their fig. 6). A maximum temperature of $c .700{ }^{\circ} \mathrm{C}$ is consistent with a 648 peridotite emplacement postdating the latest metamorphic event recorded within the 
649 ultramafic body, which occurred at conditions of $\mathrm{P}=1 \mathrm{GPa}$ and $\mathrm{T}=800-900{ }^{\circ} \mathrm{C}$

650 (obtained for the aluminous mafic rocks alternating with peridotites and sampled near

651 the marbles section studied in this work; Morishita et al., 2001). Such high P-T

652 conditions are interpreted as corresponding to a sustained synkinematic decompression

653 event (Garrido et al., 2011) that took place well before the final peridotite emplacement

654 described here. The general - though irregular - trend of increasing calcite grain size

655 with metamorphic grade observed in the studied footwall carbonates confirms the

656 fundamental control exerted by temperature on calcite recrystallization processes,

657 although the variable amount of secondary phases (Table 2) present in our impure

658 marbles is likely to have played a major role, resulting in complex calcite grain growth

659 patterns (Ebert et al. 2007a, b). As a matter of fact, the irregular distribution of calcite

660 grain size shown in Table 2 is likely to result from a complex interplay of different

661 factors including original grain size, amount of impurities, differential stress and thermal

662 regime controlling the dominant deformation mechanisms. The microstructure of calcite

663 marbles, characterized by the occurrence of undulose extinction, subgrains and new

664 recrystallized grains, is indicative of deformation by slip and climb of dislocations

665 (dislocation creep). The analysed calcite marbles show a well-developed CPO at all

666 metamorphic grades, for a wide range of grain sizes and different - though generally

667 moderate - amounts of secondary phases (Table 2). This is consistent with the

668 dominance of dislocation creep at all temperatures characterizing the studied

669 metamorphic aureole. Both microstructures and CPOs show no indications for a switch

670 in deformation mechanisms from dislocation to diffusion creep or to grain-size sensitive

671 mechanisms even at the highest temperature conditions (forsterite zone). Such an

672 interpretation is in general agreement with the experimental findings of Barnhoorn et al.

673 (2004). The associated occurrence of grain boundary migration recrystallization

674 (testified by the common presence of lobate grain boundaries) is also consistent with

675 large strains and relatively high temperatures in calcite marbles (e.g. Barnhoorn et al.,

676 2004). The generally symmetric CPO patterns suggest high-T plastic deformation,

677 dynamic recrystallization and steady-state flow, probably followed by variable degrees

678 of static recrystallization that may have weakened the CPO (Barnhoorn et al., 2005). In

679 the highest-grade forsterite zone, the presence of a carbonate melt may have also

680 contributed to a weakening of the CPO. In fact, the highest temperatures close to the

681 peridotite contact were potentially higher than the eutectic of marbles (e.g. Boettcher \&

682 Wyllie, 1969). Therefore, at least part of the microfabric suggesting static 
recrystallization associated with thermal diffusion - and the related weakened CPO could actually have resulted from grain growth following partial melting. Melt fractions - no matter how small - may additionally have controlled deformation processes in the highest-grade marbles by enhancing grain boundary sliding and migration, as well as rotation.

688 The lack of strong asymmetries in $+<\mathrm{a}>$ and $-<\mathrm{a}>$ distribution in marbles from all metamorphic zones, suggesting the occurrence of a coaxial strain component (Bestmann, 2000; Pieri et al., 2001b), is consistent with bulk deformation by general shear and/or partitioning of the deformation into zones dominated by either non-coaxial or coaxial strain. Furthermore, the occurrence of minor zones of strain localization and grain size reduction (associated with subgrain rotation recrystallization) overprinting previously annealed calcite textures (e.g. sample 09A-1) suggests a complex interplay between thermal effects and deformation events. Notwithstanding this, a final static overprint appears to be dominant in carbonates throughout the metamorphic aureole. This is consistent with the interpretation that most of the petrologic features characterizing the metamorphosed rock panel (inverted limb of the Nieves Unit regional syncline) located immediately in the footwall to the Ronda peridotites were acquired following the emplacement of the mantle extrusion wedge. Continued heat transfer from the peridotites to the footwall succession led to post-kinematic silicate growth and locally especially in the highest-T forsterite zone - to partial annealing of calcite marble textures. Following substantial cooling (Esteban et al., 2004), horizontal crustal shortening was resumed - as testified by meso-scale refolding affecting both metamorphic and non-metamorphic parts of the Nieves Unit - probably in relation with NW-ward thrusting of the 'Frontal Units' of the Internal Domain over the Flysch and External Domains (Figs. 2 to 4). Such a late, SE-NW oriented shortening of the Nieves Unit occurred at much lower temperatures, as testified by the lack of metamorphic mineral assemblages along the axial plane foliation $\left(\mathrm{S}_{2}\right)$ associated with the secondphase, NE-SW trending mesoscopic folds.

\section{Conclusions}

714 Structural analysis of the dominantly carbonate Nieves Unit located in the footwall to 715 the Ronda mantle extrusion wedge unravelled strongly heterogeneous deformation 716 accompanying a dramatic metamorphic gradient. Marbles within a several hundreds of 
717 meters-thick metamorphic aureole record high strain in the form of a well-developed

718 foliation and associated mineral lineation, accompanied by widespread isoclinal 719 intrafolial folds. Field evidence for non-coaxial strain, although clearly consistent with 720 top-to-the-NW shearing, appears to be subordinate. On the other hand, the 721 microstructures of calcite marbles - particularly the lower-T phlogopite-tremolite ones 722 effectively record top-to-the-NW kinematics, whereas their CPOs suggest the possible 723 occurrence of a coaxial strain component and therefore of an overall deformation by 724 general shear. Where asymmetry in the $c$-axis distribution is observed with respect to 725 the main composite foliation (sub-parallel to the shear plane, due to very likely high726 strain values), this appears to be synthetic with respect to the rotational component of 727 the non-coaxial strain inferred from mesoscopic kinematic criteria, this being consistent 728 with large shear strains and high-T conditions. Our results indicate that large strains and 729 attenuation of a thermally softened carbonate rock panel, probably under a general shear 730 deformation regime, dominantly controlled structural development and marble textural 731 fabrics in the metamorphic aureole in the footwall to the Ronda peridotites.

732 Petrological characteristics and mineral assemblages within the zoned metamorphic 733 aureole appear to have mostly developed after the final emplacement of the Ronda 734 mantle extrusion wedge. Post-kinematic, continued heat transfer from the hanging-wall 735 peridotites led to static growth of silicate assemblages and local partial annealing of 736 calcite marble textures, especially in the highest-T zone in the immediate footwall. 737 Following substantial cooling, renewed crustal shortening affected the Nieves Unit, 738 probably in relation with foreland-directed thrusting.

\section{Acknowledgments}

741 The paper greatly benefited from thoughtful and constructive reviews by M. Smit and

742 M. Orozco, as well as from the useful comments by Editor M. Cho. Financial support 743 by: (i) the University of Naples Federico II to SM; (ii) Project CGL-2009-09249 (MCI), 744 and Research Groups RNM-208 and RNM-3715 (JA) to AMA; and (iii) Project 745 CGL2009-12518/BTE (MEC) and Research Group RNM-145 to VLSV is gratefully 746 acknowledged. EBSD data were obtained using instrumentation funded by ARC LIEF, 747 NCRIS and Curtin University. SMR acknowledges support from Curtin University and 748 the Australian Research Council Centre of Excellence for Core to Crust Fluid Systems. 749 This is contribution 227 from the ARC CoE for Core to Crust Fluid Systems and TIGeR 750 publication no. 434. 


\section{References}

Andrieux, J., Fontbote, J.M., \& Mattauer, M. 1971. Sur un modèle explicatif de l'arc de Gibraltar. Earth and Planetary Science Letters, 12, 191-198.

Argles, T.W., Platt, J.P. \& WAters, D.J. 1999. Attenuation and excision of a crustal section during extensional exhumation: the Carratraca Massif, Betic Cordillera, southern Spain. Journal of the Geological Society of London, 156, 149-162.

BADERTSCHER, N.P. \& BURKHARD, M. 2000. Brittle-ductile deformation in the Glarus thrust Lochseiten (LK) calc-mylonite. Terra Nova, 12, 281-288.

Badertscher, N.P., Beaudoin, G., Therrien, R. \& Burkhard, M. 2002. Glarus 762 overthrust; a major pathway for the escape of fluids out of the Alpine Orogen. Geology, 30, 875-878. second critical end-point on the melting curve at 32.5 kbars and $515{ }^{\circ} \mathrm{C}$. 
784 Burkhard, M. 1993. Calcite twins, their geometry, appearance and significance as stress-strain markers and indicators of tectonic regime; a review. Journal of Structural Geology, 15, 351-368.

BusCh, J.P. \& VAN DER PlUIJM, B.A. 1995. Calcite textures, microstructures and rheological properties of marble mylonites in the Bancroft shear zone, Ontario, Canada. Journal of Structural Geology, 17, 677-688.

ConNolly, J.A.D. 1990. Multivariable phase diagrams: an algorithm based on generalized thermodynamics (4 Mb). American Journal of Science, 290, 666718.

ConNolly, J.A.D. 2009. The geodynamic equation of state: what and how. Geochemistry Geophysics Geosystems, 10, Q10014, doi:10.1029/2009GC002540.

CONNOlly, J.A.D. \& KeRRICK, D.M. 1987. An algorithm and computer program for calculating composition phase diagrams. CALPHAD, 11, 1-55.

Connolly, J.A.D. \& TROMmSdoRfF, V. 1991. Petrogenetic grids for metacarbonate rocks - pressure-temperature phase-diagram projection for mixed-volatile systems. Contributions to Mineralogy and Petrology, 108, 93-105.

Cuevas, J., Esteban, J.J. \& TubÍA, J.M. 2006. Tectonic implications of the granite dyke swarm in the Ronda peridotites (Betic Cordilleras, Southern Spain). Journal of the Geological Society, London, 163, 631-640.

De BRESSER, J.H.P. \& SPIERS, C.J. 1997. Strength characteristics of the r, f, and c slip systems in calcite. Tectonophysics, 272, 1-23.

Didon, J., Durand-Delga M. \& KornProbST, J. 1973. Homologies géologiques entre les deux rives du Détroit de Gibraltar. Bulletin de la Societé géologique de France, 15, 77-105.

DÜRR, S.H. 1967. Geologie der Serrania de Ronda und ihrer südweslichen Ausläufer (Andalusien). Geologica Romana, 6, 1-73.

Ebert, A., Herwegh, M., Evans, B., Pfiffner, A., Austin, N. \& Vennemann, T. 2007a. Microfabrics in carbonate mylonites along a large-scale shear zone (Helvetic Alps). Tectonophysics, 444, 1-26, doi:10.1016/j.tecto.2007.07.004.

Ebert, A., Herwegh, M. \& Pfiffner, A. 2007b. Cooling induced strain localization in carbonate mylonites within a large-scale shear zone (Glarus thrust, Switzerland). Journal of Structural Geology, 29, 1164-1184, doi:10.1016/j.jsg.2007.03.007. 
817 Esteban, J.J., Cuevas, J., Tubía, J.M., Gil-Ibarguchi, J.I. \& Seward, D. 2005. 818 Metamorfismo, exhumación y termocronología de la unidad de Yunquera 819 (Alpujárrides occidentales, Cordilleras Béticas). Revista de la Sociedad $820 \quad$ Geológica de España, 18, 61-74.

821 Esteban, J.J., SÁnchez-Rodríguez, L., Seward, D., Cuevas, J. \& Tubía, J.M. 2004.

822 The late thermal history of the Ronda area. Tectonophysics, 389, 81-92.

823 Esteban, J.J., Cuevas, J., Tubía, J.M., Liati, A., Seward, D. \& Gebauer, D. 2007.

824 Timing and origin of zircon-bearing chlorite schists in the Ronda peridotites 825 (Betic Cordilleras, Southern Spain). Lithos, 99, 121-135.

826 Esteban, J.J., Cuevas, J.,Vegas, N. \& Tubía J.M. 2008. Deformation and kinematics in a melt-bearing shear zone from the Western Betic Cordilleras (Southern Spain). Journal of Structural Geology, 30, 380-393.

Esteban, J.J., Tubía, J.M., Cuevas, J.,Vegas, N., Sergeev, S. \& Larionov, A. 2011. Peri-Gondwanan provenance of pre-Triassic metamorphic sequences in the western Alpujarride nappes (Betic Cordillera, southern Spain). Gondwana Research, 20, 443-449, doi:10.1016/j.gr.2010.11.006

Garrido, C.J., Gueydan, F., Booth-Rea, G., Precigout, J., Hidas, K., PadrónNAVARTA, J.A. \& MARCHESI, C. 2011. Garnet lherzolite and garnet-spinel mylonite in the Ronda peridotite: Vestiges of Oligocene backarc mantle lithospheric extension in the western Mediterranean. Geology, 39, 927-930, doi:10.1130/G31760.1.

HeitzmanN, P. 1987. Calcite mylonites in the Central Alpine "root zone". Tectonophysics, 135, 207-215.

Hoeppener, R., Hoppe, H., Mollat, H., Muchow, S. Dürr, S.H. \& Kockel, F. 1963. Über den westlichen abschnitt der Betischen Kordilleren und seine beziehungen zum gesamtorogen. Geologische Rundschau, 53, 269-296.

Hoeppener, R., Hoppe, H., DüRR, S.H. \& Mollat, H. 1964. Ein querschnitt durch die Betischen Kordilleren bei Ronda (SW Spanien). Geologie en Mijnbouw, 43, 282-298.

Holland, T. J. B. \& Powell, R. 1998. An internally consistent thermodynamic data set for phases of petrologic interest. Journal of Metamorphic Geology, 16, 309-343.

iannace, A., Bonardi, G., D’Errico, M., Mazzoli, S., Perrone, V. \& Vitale, S. 2005. Structural setting and tectonic evolution of the Apennine Units of northern Calabria. Comptes Rendus-Geoscience, 337, 1541-1550. 
Iannace, A., Vitale, S., D’Errico, M., et AL. 2007. The Lungro-Verbicaro Unit (northern Calabria, Italy): A record of Tethyan paleomargin evolution and Miocene convergence, continental subduction, and exhumation of HP-LT rocks. Journal of the Geological Society, London, 164, 1165-1186, doi:10.1144/001676492007-017.

LundeEn, M.T. 1978. Emplacement of the Ronda peridotite, Sierra Bermeja, Spain. Geological Society of America Bulletin, 89, 172-180.

MARTín-Algarra, A. 1987. Evolución geológica alpina del contacto entre las Zonas Internas y las Zonas Externas de la Cordillera Bética. [Ph. D. Thesis] University of Granada, $1171 \mathrm{p}$.

MARtín-AlgarRA, A. 2004 (coord.). Unidades Frontales de las Zonas Internas. In: Vera, J.A. (ed.) Geología de España, Sociedad Geológica de España - Instituto Geológico y Minero de España, Madrid, 396-401.

Martín-Algarra, A. \& Estevez A. 1984. La brèche de la Nava: dépôt continental synchrone de la structuration pendant le Miocène inférieur des Zones Internes de l'ouest des Cordillères Bétiques. Comptes Rendus de l'Académie de Sciences de Paris, 299, 463-466.

Martin-Algarra, A., Mazzoli, S., Perrone, V. \& Rodriguez-Cañero, R. 2009. Variscan tectonics in the Malaguide Complex (Betic Cordillera, Southern Spain): stratigraphic and structural Alpine vs. pre-Alpine constraints from the Ardales area (Province of Malaga). II: Structure. Journal of Geology, 117, 263-284.

Martín-Algarra, A., O'Dogherty, L., Aguado, R. \& Gursky, H.J. 1998. Estratigrafía, petrografía y significado paleogeográfico de las radiolaritas jurásicas de tipo austroalpino de la unidad de las Nieves (Formación Parauta, Rondaides, Cordillera Bética Occidental). Geogaceta, 24, 211-214.

Martín-Algarra, A. \& Vera, J.A. 2004. Evolución de la Cordillera Bética. In: VerA, J.A. (ed.) Geología de España, Sociedad Geológica de España - Instituto Geológico y Minero de España, Madrid, 437-444.

Mazzoli, S. \& MARTín-AlgarRA, A. 2011. Deformation partitioning during transpressional emplacement of a 'mantle extrusion wedge': the Ronda peridotites, western Betic Cordillera, Spain. Journal of the Geological Society, 168, 373-382, doi:10.1144/0016-76492010-126. 
883

884

885

886

887

888

889

890

891

892

893

894

895

896

897

898

899

900

901

902

903

904

905

906

907

908

909

910

911

912

913

914

915

916

Morishita, T., Arai, S. \& Gervilla, F. 2001. High-pressure aluminous mafic rocks from the Ronda peridotite massif, southern Spain: significance of sapphirineand corundum-bearing mineral assemblages. Lithos, 57, 143-161.

OBAtA, M. 1980. The Ronda peridotite: garnet-, spinel-, and plagioclase lherzolite facies and the P-T trajectories of a high temperature mantle intrusion. Journal of Petrology, 21, 533-572.

O'Dogherty, L., Martín-Algarra, A., Gursky, H.J. \& Aguado, R. 2001. The Middle Jurassic radiolarites and pelagic limestones of the Nieves Unit (Rondaide Complex, Betic Cordillera): Basin starvation in a rifted marginal slope of the western Tethys. International Journal of Earth Sciences (Geol. Rundsch.), 90, 831-846.

Orozco, M. \& Alonso-Chaves, F.M. 2012. Kilometre-scale sheath folds in the western Betics (south of Spain). International Journal of Earth Sciences (Geol Rundsch), 101, 505-519.

PfIFFNER, O. A. 1982. Deformation mechanisms and flow regimes in limestones from the Helvetic Zone of the Swiss Alps. Journal of Structural Geology, 4, 429-442.

Pieri, M., Burlini, L., Kunze, K., OlgaArd, D.L. \& Stretton, I.C. 2001a. Rheological and microstructural evolution of Carrara marble with high shear strain: results from high temperature torsion experiments. Journal of Structural Geology, 23, 1393-1413.

Pieri, M., Kunze, K., Burlini, L., Stretton, I.C., OlgaArd, D.L., BurG, J.-P. \& WENK, H.R. 2001b. Texture development of calcite by deformation and dynamic recrystallisation at $1000 \mathrm{~K}$ during torsion experiments of marble to large strains. Tectonophysics, 330, 119-140.

Platt, J. P., Argles, T. W., Carter, A., et AL. 2003. Exhumation of the Ronda peridotite and its crustal envelope: constraints from thermal modelling of a P-Ttime array. Journal of the Geological Society, 160, 655-676.

Renner, J., Evans, B. \& SiddiqI, G. 2002. Dislocation creep of calcite. Journal of Geophysical Research, 107 (B12), 2364, doi:10.1029/2001JB001680.

RICE, J.M. 1977. Progressive metamorphism of impure dolomitic limestone in the Marysville Aureole, Montana. American Journal of Science, 277, 1-24.

RICE, J.M. 1980. Phase equilibria involving humite minerals in impure dolomitic limestones. Part I. Calculated stability of clinohumite. Contributions to Mineralogy and Petrology, 71, 219-235. 
917 Rutter, E.H., CAsey, M. \& Burlini, L. 1994. Preferred crystallographic orientation

918 development during the plastic and superplastic flow of calcite rocks. Journal of

919 Structural Geology, 16, 1431-1446.

920 SÁnchez-Navas, A., De Oliveira-Barbosa, R.D.C., García-Casco, A. \& Martín-

921 Algarra, A. 2012. Transformation of andalusite to kyanite in the Alpujarride

922 Complex (Betic Cordillera, S Spain): Geologic implications. Journal of

923 Geology, 120, 557-574. doi:10.1086//666944.

924 SÁnchez Rodríguez L. \& Gebauer, D. 2000. Mesozoic formation of pyroxenites and

925 gabbros in the Ronda area (southern Spain), followed by Early Miocene

926 subduction metamorphism and emplacement into the middle crust: U-Pb

927 sensitive high-resolution ion microprobe dating of zircon. Tectonophysics, 316,

$928 \quad 19-44$.

929 Schmid, S.M., Boland, J.N. \& PATERSON, M.S. 1977. Superplastic flow in finegrained 930 limestone. Tectonophysics, 43, 257-291.

931 Schmid, S.M., PATERSON, M.S. \& Boland, J.N. 1980. High temperature flow and 932 dynamic recrystallisation in Carrarra marble. Tectonophysics, 65, 245-280.

933 Schmid, S.M., PAnozzo, R. \& BAuer, S. 1987. Simple shear experiments on calcite 934 rocks: rheology and microfabric. Journal of Structural Geology, 9, 747-778.

935 TrommsdorfF, V. \& ConNolly, J.A.D. 1990. Constraints on phase diagram topology

936 for the system: $\mathrm{CaO}-\mathrm{MgO}-\mathrm{SiO}_{2}-\mathrm{H}_{2} \mathrm{O}-\mathrm{CO}_{2}$. Contributions to Mineralogy and 937 Petrology, 104, 1-7.

938 TuBÍA, J.M. 1994. The Ronda peridotites (Los Reales nappe): an example of the 939 relationship between lithospheric thickening by oblique tectonics and late 940 extensional deformation within the Betic Cordillera (Spain). Tectonophysics, $941 \quad$ 238, 381-398.

942 TubíA, J. M. \& Cuevas, J. 1986. High-temperature emplacement of the Los Reales 943 peridotite nappe (Betic Cordillera, Spain). Journal of Structural Geology, 8, $944 \quad 473-482$.

945 Tubía, J.M., Cuevas, J. \& Gil IBARguchi, J.I. 1997. Sequential development of the 946 metamorphic aureole beneath the Ronda peridotites and its bearing on the 947 tectonic evolution of the Betic Cordillera. Tectonophysics, 279, 227-252.

948 TubíA, J. M. \& Gil IBARguchi, I. 1991. Eclogites of the Ojén nappe: a record of 949 subduction in the Alpujárride Complex (Betic Cordilleras, southern Spain). $950 \quad$ Journal of the Geological Society, London, 148, 801-804. 
951 Ulrich, S., Schulmann, K. \& Casey, M. 2002. Microstructural evolution and 952 rheological behaviour of marbles deformed at different crustal levels. Journal of 953 Structural Geology, 24, 979-995.

954 VAN DER WAL, D. \& VISSERS, R.L.M. 1996. Structural petrology of the Ronda peridotite, 955 SW Spain: deformation history. Journal of Petrology, 37, 23-43.

956 Van Wees, J.D., De Jong, K. \& Cloeting, S. 1992. Two-dimensional P-T-t modelling 957 and the dynamics of extension and inversion in the Betic Zone (SE Spain). 958 Tectonophysics, 203, 305-324.

959 Vitale, S. \& Mazzoli, S. 2005. Influence of object concentration on finite strain and 960 effective viscosity contrast: insights from naturally deformed packstones. 961 Journal of Structural Geology, 27, 2135-2149.

962 Vitale, S. \& Mazzoli, S. 2009. Finite strain analysis of a natural ductile shear zone in 963 limestones: insights into 3-D coaxial vs. non-coaxial deformation partitioning. 964 Journal of Structural Geology, 31, 104-113, doi:10.1016/j.jsg.2008.10.011.

965 Vitale, S., White, J.C., IAnNace, A. \& MAZzoli, S. 2007. Ductile strain partitioning in 966 micritic limestones, Calabria, Italy: the roles and mechanisms of intracrystalline 967 and intercrystalline deformation. Canadian Journal of Earth Sciences, 44, 1587$968 \quad 1602$.

969 Wenk, H.R. 1985. Carbonates. In: Preferred Orientation in Deformed Metals and Rocks. 970 An Introduction to Modern Texture Analysis, Academic Press, pp. 361-384.

971 Whitney, D.L. \& Evans B.W., 2010. Abbreviations for names of rock-forming 972 minerals. American Mineralogist, 95, 185-187.

973 


\section{$974 \quad$ Figure Captions}

976 Fig. 1. Tectonic sketch map of the Betic Cordillera, showing the Ronda peridotites outcrop area (boxed SW-most sector).

978

Fig. 2. Tectonic sketch map of the western Betic Cordillera and regional geological cross-section X-X' (after Mazzoli and Martín-Algarra, 2011, modified). Box shows location of area mapped in detail (Fig. 3).

982

983 Fig. 3. Geological map of field study area (showing sample location) and trace of cross984 section reproduced in Fig. 4.

986 Fig. 4. Geological cross-section (roughly parallel to the Ronda-San Pedro de Alcantara road) through the leading edge of the Ronda peridotites at Sierra Bermeja (after Mazzoli and Martín-Algarra, 2011, modified), showing projected location of the studied samples. Zoning of the metamorphic aureole (shaded) in the Nieves Unit is shown by means of the following index minerals: talc (tc), phlogopite (phl), tremolite (tr), diopside (di), and

991 forsterite (fo). Key for stratigraphic units: (1) Norian dolostones and (1') dolomite 992 marbles; (2) Rhaetian marls and (2') calcschists; (3) Rhaetian limestones and (3') calcite 993 marbles; (4) Lower Jurassic cherty limestones and marls and (4') marbles including quartz lenses and calcschists; (5) Middle Jurassic-Paleogene (mainly marly) condensed succession and (5') calc-schists; (6) Nava Breccia Fm.

996

997 Fig. 5. Field examples of structural features in the Nieves Unit in the footwall to the 998 Ronda peridotites. (A) View of the tectonic contact with the overlying Ronda peridotites 999 (Cerro Corona area). (B) View of the hinge zone of the regional syncline, including 1000 second-order overturned folds (Fuenfría area). (C) Composite planar fabric $\left(\mathrm{S}_{0}-\mathrm{S}_{1}\right)$ in 1001 dolomite marble (km 19.5 of the A-473 road from Ronda to San Pedro de Alcantara). (D) 1002 Close-up of the boxed area in (C), showing minor folds in the hinge zone of a larger 1003 syncline. (E) Composite planar fabric $\left(\mathrm{S}_{0}-\mathrm{S}_{1}\right.$; horizontal) in metamorphosed Jurassic 1004 cherty limestones (Torrecilla area). Note symmetric pressure shadows around framboidal 1005 pyrite grains (arrowed). (F) Composite planar fabric $\left(\mathrm{S}_{0}-\mathrm{S}_{1}\right)$ displaced and overgrown by 1006 phlogopite-tremolite clot in metamorphosed Norian levels (dolomite marbles of the 1007 Cerro Alcojona area). 
1009 Fig. 6. Outcrop examples of structural features in the Nieves Unit. (A) Mineral lineation

$1010\left(\mathrm{~L}_{1}\right)$ defined by elongated tremolite (arrowed) and dolomite crystals lying on the main

1011 foliation in metamorphosed Norian levels (dolomite marbles at km 19.5 of the A-473

1012 road from Ronda to San Pedro de Alcantara). (B) Early intrafolial folds in dolomite

1013 marbles (Cerro Alcojona area). (C) Late (post-metamorphic) folds affecting the main

1014 composite planar fabric $\left(\mathrm{S}_{0}-\mathrm{S}_{1}\right)$ in dolomite marbles $(\mathrm{km} 19.5$ of the A-473 road from

1015 Ronda to San Pedro de Alcantara). (D) Asymmetric (z-shaped looking towards SW)

1016 parasitic folds affecting bedding $\left(\mathrm{S}_{0}\right)$ in the normal limb of the regional syncline

1017 (Jurassic cherty limestones of the Torrecilla area). (E) Late kink bands affecting the

1018 main composite planar fabric $\left(\mathrm{S}_{0}-\mathrm{S}_{1}\right)$ along the San Pedro de Alcantara road.

1019

1020 Fig. 7. Orientation data (lower hemisphere, equal-area projections) for structures in the

1021 Nieves Unit. (A) Poles to bedding $\left(\mathrm{S}_{0}\right) /$ composite planar fabric $\left(\mathrm{S}_{0}-\mathrm{S}_{1}\right.$; metamorphic

1022 aureole); pole to the best-fit great circle (or $\pi$-girdle, plunging $19^{\circ}$ toward $54^{\circ} \mathrm{N}$ )

1023 provides a statistical axis consistent with NE-SW trending folding. (B) Mineral lineation

$1024\left(\mathrm{~L}_{1}\right)$ in silicate-bearing marbles. (C) Hinges of isoclinal, intrafolial folds. (D) Poles to

1025 axial surfaces of isoclinal, intrafolial folds. (E) Hinge lines of late, open to tight folds

1026 within metamorphic aureole. (F) Poles to axial surfaces of late, open to tight folds within

1027 metamorphic aureole.

1028

1029 Fig. 8. Thin section microphotographs (crossed polars) showing representative 1030 petrological and microstructural features of the studied marble samples (mineral name 1031 abbreviations after Whitney and Evans, 2010). (A) Intensely deformed, high-T calcite 1032 marble (sample 09A-02; forsterite zone). (B) Granoblastic, mainly dolomite marble 1033 (with scarce, "dusty" calcite grains) with a thin folded layer of phlogopite (sample 09A1034 15; tremolite zone). (C) Palmed aggregate of amphibole subparallel to the main rock 1035 foliation as indicated by the white dashed line (sample 09A-16; tremolite zone). (D) 1036 Xenoblastic spinel grains associated with calcite and large phlogopite flakes (sample 1037 09A-11; tremolite zone). (E) Typical mineral assemblage of clinopyroxene, calcite and 1038 quartz-bearing rock (sample 09A-08; diopside zone). (F) Hypidioblastic clinopyroxene 1039 and amphibole grains overgrowing strongly deformed calcite grains (sample 09A-01; 1040 forsterite zone). (G) Typical high-grade mineral assemblage of olivine-clinohumite1041 spinel marble close to the contact with peridotite (sample 09A-24; forsterite zone). (H) 
1042 High-T calcite marble (sample 09A-3; forsterite zone) showing lobate grain boundaries 1043 (red arrows), straight grain boundaries and triple junctions (yellow arrows) and 1044 secondary foliation (sf) defined by recrystallized grains oblique to the main composite 1045 foliation (horizontal; NW is to the right of the picture). (I) High-T marble with equant 1046 calcite grains showing both lobate and straight boundaries (sample 09A-25; forsterite 1047 zone). (J) Lower-T calcite marble (sample 09A-19; tremolite zone) displaying S-C-C' 1048 fabrics (NW is to the right of the picture). (K) Lower-T calcite marble (sample 09A-20; 1049 phlogopite zone) showing secondary foliation (sf) defined by recrystallized grains 1050 oblique to the main composite foliation (horizontal; NW is to the right of the picture).

1052 Fig. 9. Calculated $\mathrm{P}-\mathrm{T}$ projections for the $\mathrm{K}_{2} \mathrm{O}-\mathrm{CaO}-\mathrm{MgO}-\mathrm{Al}_{2} \mathrm{O}_{3}-\mathrm{SiO}_{2}-\mathrm{H}_{2} \mathrm{O}-\mathrm{CO}_{2}$ system 1053 with the following minerals (abbreviations after Whitney and Evans, 2010): calcite 1054 (Cal), clinochlore ( $\mathrm{Clc})$, clinohumite (Chu), diopside (Di), dolomite (Dol), forsterite 1055 (Fo), microcline (Mc), phlogopite (Phl), quartz (Qz), spinel (Spl) and tremolite (Tr). 1056 Abbreviation for the fluid solution is F. All curves in (A) correspond to univariant 1057 equilibria. Field b-d in (A) is enlarged in diagrams (B), (C) and (D). Note that minimum 1058 pressure in these cases widens towards $50 \mathrm{MPa}$. Thick and thin dashed curves 1059 correspond to univariant and pseudounivariant equilibria, respectively (see text for 1060 details). Big circles and small filled circles along univariant curves correspond to 1061 invariant and pseudoinvariant points, respectively. Different grey areas represent 1062 divariant fields in which pseudounivariant equilibria are stable with the same solid 1063 phases and changing fluid composition ( $\mathrm{X}_{\mathrm{CO} 2}$ always increases with temperature). In 1064 (D), thick dashed line at a constant pressure of $300 \mathrm{MPa}$ acts as reference for obtaining 1065 the temperature ranges for the relevant phases observed in the studied rocks (upper part 1066 of the diagram).

1068 Fig. 10. CPO data for calcite marble samples from: (i) forsterite zone (09A-1, 09A-3); 1069 (ii) diopside zone (09A-7); (iii) tremolite zone (09A-18, 09A-19); and (iv) phlogopite 1070 zone (09A-20). Dolomite marble sample (09A-15) is from the tremolite zone. All 1071 projections are lower hemisphere and equal area. Contour lines are at intervals of 0.5 1072 Multiples of Uniform Density (MUD) and the maximum MUD is given to two 1073 significant figures. For forsterite zone samples, heterogeneous grain size gives rise to a 1074 grain-size dependent bias in standard pole figures. For 09A-1 and 09A-3 data are 1075 therefore shown as 1 point per grain. For other samples, pole figure data (columns 1-5) 
1076 represents all of the collected EBSD data. For comparison, 1 point per grain data for all 1077 samples is given in column 6, along with the MUD and the total number of analysed 1078 grains. Misorientation axes data are calculated for minimum angular misorientations 1079 between adjacent EBSD analyses of $2-10^{\circ}$ and are given with MUD and number of 1080 misorientation axes. Orientation of oblique foliation is indicated in column 1 for 1081 samples (09A-3, 19, 20) whose microstructure is shown in Fig. 8. 
Table 1: Mineral assemblages of the studied marbles. Names abbreviations after Whitney and Evans (2010)

\begin{tabular}{|c|c|c|c|c|c|c|c|c|c|c|c|c|c|c|c|c|}
\hline Samp. Area* & Met. Zone*** & Sample & Cal & Dol & $\mathrm{Qz}$ & Mc & Chl & Phl & Amp & Cpx & Scp & OI & Chu & Spl & Sph & Mag \\
\hline $\mathrm{CC}$ & \multirow{9}{*}{ 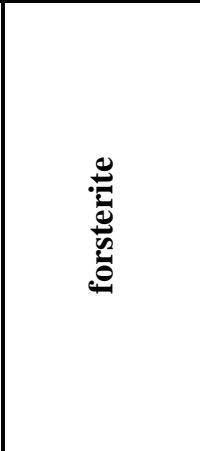 } & 09A-1 & $\mathrm{x}$ & & $\mathrm{x}$ & & & $\mathrm{x}$ & $\mathrm{x}$ & $\mathrm{x}$ & & & & & & \\
\hline $\mathrm{CC}$ & & 09A-2 & $\mathrm{x}$ & & & & & $\mathrm{x}$ & & & & $\mathrm{x}$ & & & & \\
\hline $\mathrm{CC}$ & & 09A-3 & $\mathrm{x}$ & & & & & & $\mathrm{x}$ & & & $\mathrm{x}$ & & & & $\mathrm{x}$ \\
\hline $\mathrm{CC}$ & & 09A-4 & $\mathrm{x}$ & $\mathrm{x}$ & & & $\mathrm{x}$ & $\mathrm{x}$ & $\mathrm{x}$ & & & $\mathrm{x}$ & & $\mathrm{x}$ & & $\mathrm{x}$ \\
\hline $\mathrm{CA}$ & & 09A-21 & $\mathrm{x}$ & $\mathrm{x}$ & & & & $\mathrm{x}$ & $\mathrm{x}$ & & & $\mathrm{x}$ & $\mathrm{x}$ & $\mathrm{x}$ & & $\mathrm{x}$ \\
\hline $\mathrm{CA}$ & & 09A-22 & $\mathrm{x}$ & $\mathrm{x}$ & & & & $\mathrm{x}$ & $\mathrm{x}$ & & & $\mathrm{x}$ & & $\mathrm{x}$ & & $\mathrm{x}$ \\
\hline $\mathrm{CA}$ & & 09A-23 & $\mathrm{x}$ & $\mathrm{x}$ & & & & $\mathrm{x}$ & $\mathrm{x}$ & & & & & & & $\mathrm{x}$ \\
\hline $\mathrm{CA}$ & & 09A-24 & $\mathrm{x}$ & $\mathrm{x}$ & & & & $\mathrm{x}$ & $\mathrm{x}$ & & & $\mathrm{x}$ & $\mathrm{x}$ & $\mathrm{x}$ & & $\mathrm{x}$ \\
\hline $\mathrm{CA}$ & & 09A-25 & $\mathrm{x}$ & & & & & $\mathrm{x}$ & $\mathrm{x}$ & & & & & & & $\mathrm{x}$ \\
\hline $\mathrm{CC}$ & \multirow{5}{*}{ 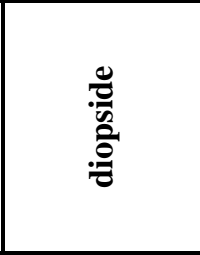 } & $09 \mathrm{~A}-5$ & $\mathrm{x}$ & & $\mathrm{x}$ & & & $x$ & & $\mathrm{x}$ & & & & & & $\mathrm{x}$ \\
\hline $\mathrm{CC}$ & & 09A-6 & $\mathrm{x}$ & & $\mathrm{x}$ & & & $\mathrm{x}$ & $\mathrm{x}$ & $\mathrm{x}$ & $\mathrm{x}$ & & & & $\mathrm{x}$ & $\mathrm{x}$ \\
\hline $\mathrm{CC}$ & & 09A-7 & $\mathrm{x}$ & & $\mathrm{x}$ & & & $\mathrm{x}$ & & & & & & & & $\mathrm{x}$ \\
\hline $\mathrm{CC}$ & & 09A-8 & $\mathrm{x}$ & & $\mathrm{x}$ & $\mathrm{x}$ & & $\mathrm{x}$ & & $\mathrm{x}$ & $\mathrm{x}$ & & & & $\mathrm{x}$ & $\mathrm{x}$ \\
\hline $\mathrm{CC}$ & & 09A-9 & $\mathrm{x}$ & & $\mathrm{x}$ & & & $\mathrm{x}$ & $\mathrm{x}$ & $\mathrm{x}$ & & & & & $\mathrm{x}$ & $\mathrm{x}$ \\
\hline $\mathrm{CC}$ & \multirow{10}{*}{ 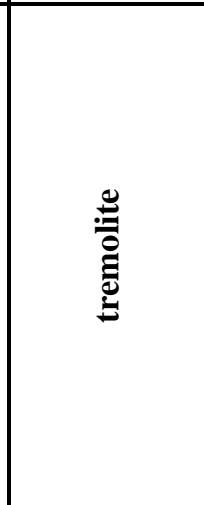 } & 09A-10 & $\mathrm{x}$ & $\mathrm{x}$ & & & & $\mathrm{x}$ & & & & & & & & $\mathrm{x}$ \\
\hline $\mathrm{CC}$ & & 09A-11 & $\mathrm{x}$ & $\mathrm{x}$ & & & & $\mathrm{x}$ & $\mathrm{x}$ & & & & & $\mathrm{x}$ & & $\mathrm{x}$ \\
\hline $\mathrm{CC}$ & & 09A-12 & $\mathrm{x}$ & $\mathrm{x}$ & $\mathrm{x}$ & & & $\mathrm{x}$ & $\mathrm{x}$ & & & & & & & $\mathrm{x}$ \\
\hline $\mathrm{CC}$ & & 09A-13 & $\mathrm{x}$ & $\mathrm{x}$ & & & & $\mathrm{x}$ & & & & & & & & $\mathrm{x}$ \\
\hline $\mathrm{CC}$ & & 09A-14 & $\mathrm{x}$ & $\mathrm{x}$ & & & & $\mathrm{x}$ & & & & & & & & $\mathrm{x}$ \\
\hline $\mathrm{CC}$ & & 09A-15 & $\mathrm{x}$ & $\mathrm{x}$ & & & & $\mathrm{x}$ & & & & & & & & $\mathrm{x}$ \\
\hline $\mathrm{CC}$ & & 09A-16 & $\mathrm{x}$ & $\mathrm{x}$ & & & $\mathrm{x}$ & $\mathrm{x}$ & $\mathrm{x}$ & & & & & & & $\mathrm{x}$ \\
\hline $\mathrm{CC}$ & & 09A-17 & $\mathrm{x}$ & $\mathrm{x}$ & & & & $\mathrm{x}$ & $\mathrm{x}$ & & & & & & & $\mathrm{x}$ \\
\hline $\mathrm{CC}$ & & 09A-18 & $\mathrm{x}$ & $\mathrm{x}$ & & & & $\mathrm{x}$ & $\mathrm{x}$ & & & & & & & $\mathrm{x}$ \\
\hline $\mathrm{CC}$ & & 09A-19 & $\mathrm{x}$ & & & & & $\mathrm{x}$ & & & & & & & & $\mathrm{x}$ \\
\hline $\mathrm{CC}$ & phlogopite & 09A-20 & $x$ & & $\mathrm{x}$ & & & $\bar{x}$ & & & & & & & & $\bar{x}$ \\
\hline
\end{tabular}

* Sampling area. CC: Cerro de los Cascajares; CA: Cerro Alcojona

** Metamorphic zone, after Martín-Algarra (1987) 
Table 2: Modal analysis and carbonate grain size analysis of the studied marbles.

\begin{tabular}{|c|c|c|c|c|c|c|}
\hline $\begin{array}{c}\text { Sampling } \\
\text { Area* }\end{array}$ & $\begin{array}{l}\text { Metamorphic } \\
\text { Zone** }\end{array}$ & Sample & Impurities & Dmin & Dmax & Dmedian \\
\hline $\mathrm{CC}$ & \multirow{2}{*}{ } & 09A-1 & $\begin{array}{c}6.5 \\
n=4700\end{array}$ & 9 & 1329 & $\begin{array}{c}178( \pm 153) \\
\mathrm{n}=713\end{array}$ \\
\hline $\mathrm{CC}$ & & 09A-3 & $\begin{array}{c}6.8 \\
n=6000\end{array}$ & 68 & 2083 & $\begin{array}{c}230( \pm 136) \\
\mathrm{n}=512\end{array}$ \\
\hline $\mathrm{CC}$ & diopside & 09A-7 & $\begin{array}{c}12.0 \\
\mathrm{n}=8000\end{array}$ & 35 & 429 & $\begin{array}{c}111( \pm 52) \\
n=705\end{array}$ \\
\hline $\mathrm{CC}$ & \multirow{4}{*}{ } & 09A-12 & $\begin{array}{c}10.1 \\
\mathrm{n}=10000\end{array}$ & 51 & 1586 & $\begin{array}{c}354( \pm 244) \\
\mathrm{n}=561\end{array}$ \\
\hline $\mathrm{CC}$ & & 09A-15 & $\begin{array}{c}7.2 \\
\mathrm{n}=5000\end{array}$ & 55 & 666 & $\begin{array}{c}143( \pm 59) \\
\mathrm{n}=1218\end{array}$ \\
\hline $\mathrm{CC}$ & & 09A-18 & $\begin{array}{c}17.8 \\
\mathrm{n}=8000\end{array}$ & 22 & 394 & $\begin{array}{c}70( \pm 31) \\
\mathrm{n}=740\end{array}$ \\
\hline $\mathrm{CC}$ & & 09A-19 & $\begin{array}{c}16.6 \\
n=10000\end{array}$ & 12 & 96 & $\begin{array}{c}30( \pm 12) \\
\mathrm{n}=619\end{array}$ \\
\hline $\mathrm{CC}$ & phlogopite & 09A-20 & $\begin{array}{c}11.0 \\
\mathrm{n}=10000\end{array}$ & 26 & 437 & $\begin{array}{c}112( \pm 55) \\
\mathrm{n}=614\end{array}$ \\
\hline
\end{tabular}

* CC: Cerro de los Cascajares.

** After Martín-Algarra (1987).

Impurities $=$ abundance of the non-carbonate minerals (in vol. $\% ; n=$ number of counted points); Dmin = minimum size (in $\mu \mathrm{m}$ ) of the carbonate minerals; Dmax = maximum size (in $\mu \mathrm{m}$ ) of the carbonate minerals; Dmedian $=$ median size $($ in $\mu \mathrm{m}$ ) of the carbonate minerals (standard deviation values reported in brackets; $\mathrm{n}=$ number of measured grains). 


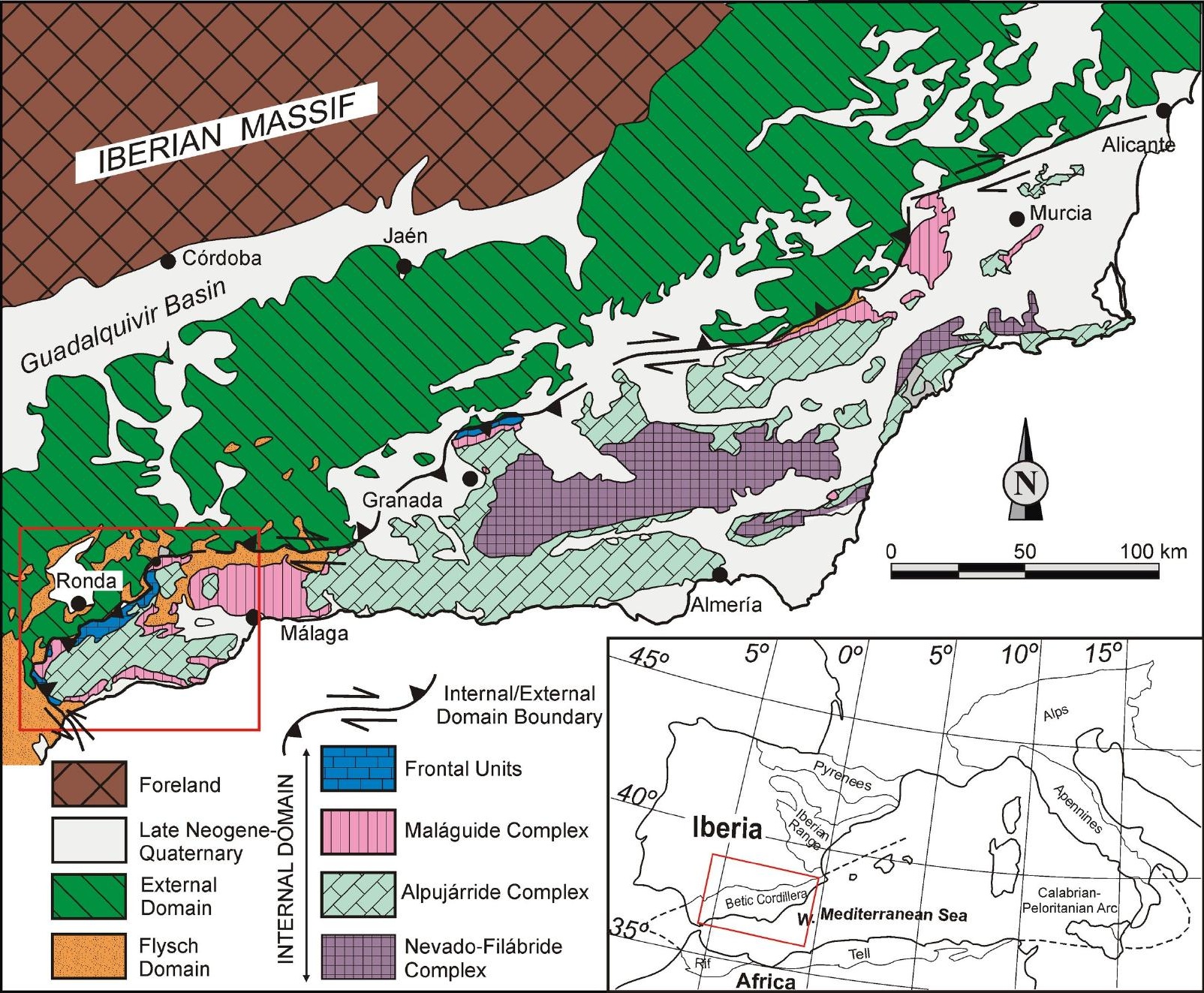




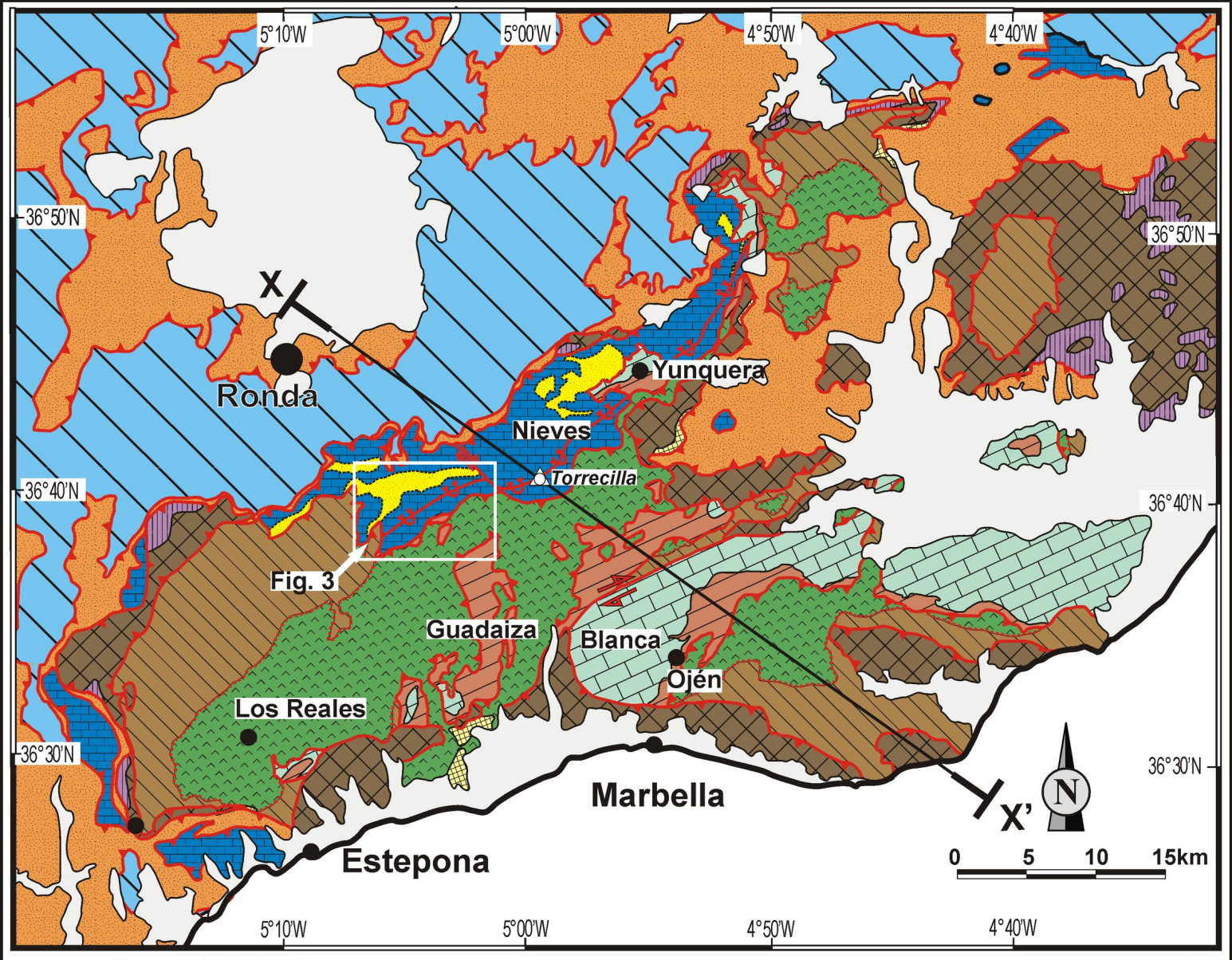

\section{$\mathrm{x}$}

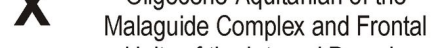

Viñuela Group (eroded)

Backthrusted Campo de Gibraltar Complex

$\mathbf{X}^{\prime}$

NW

Units of the Internal Domain

Sierra de
las Nieves

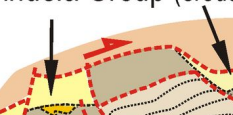
onto the Internal Domain (eroded)

SE

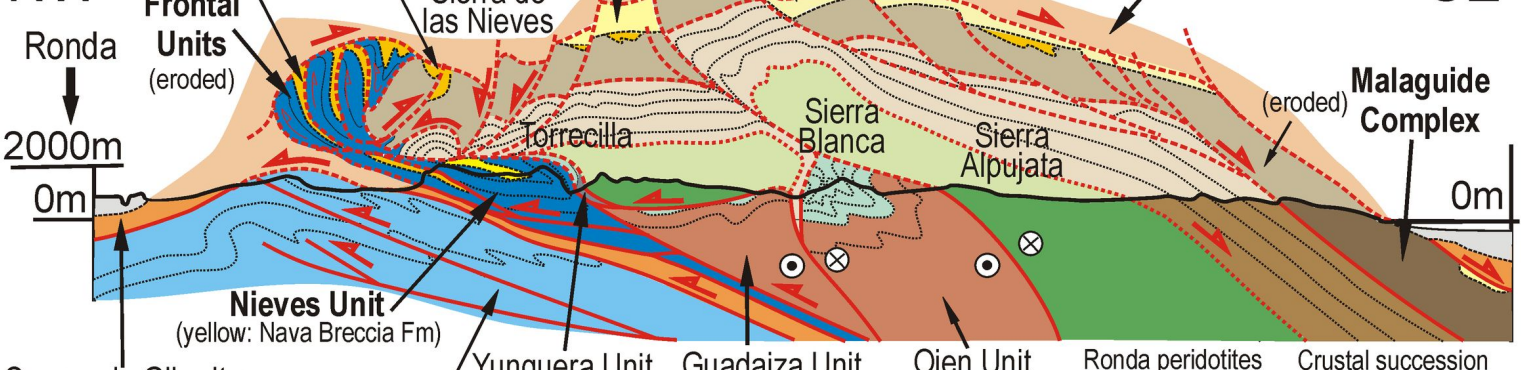

Campo de Gibraltar

Complex

Yunquera Unit Guadaiza Unit Ojen Unit

Ronda peridotites

Crustal succession

(Flysch Domain) (External Domain)

Penibetic

Blanca-type Units

Los Reales Nappe

Postorogenic Deposits

(Late Miocene-Holocene)

External Domain

Torrecilla Syncline ש

Top of the Ronda peridotite

Thrusts Footwall Hangingwall

Dextral strike-slip $\odot \mid \otimes$
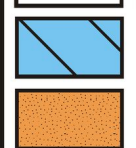

\section{Flysch Domain}

Alpujarride Complex 


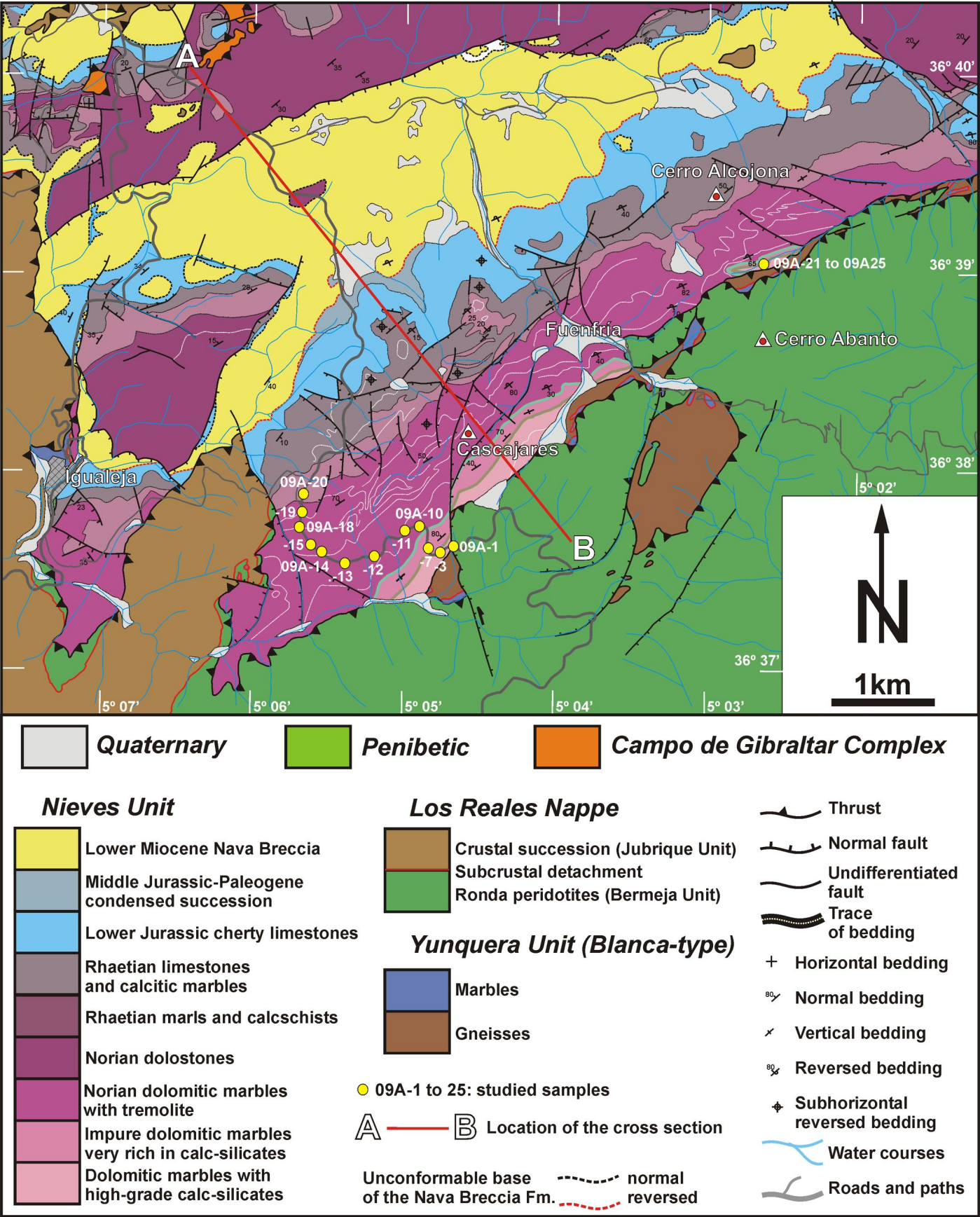




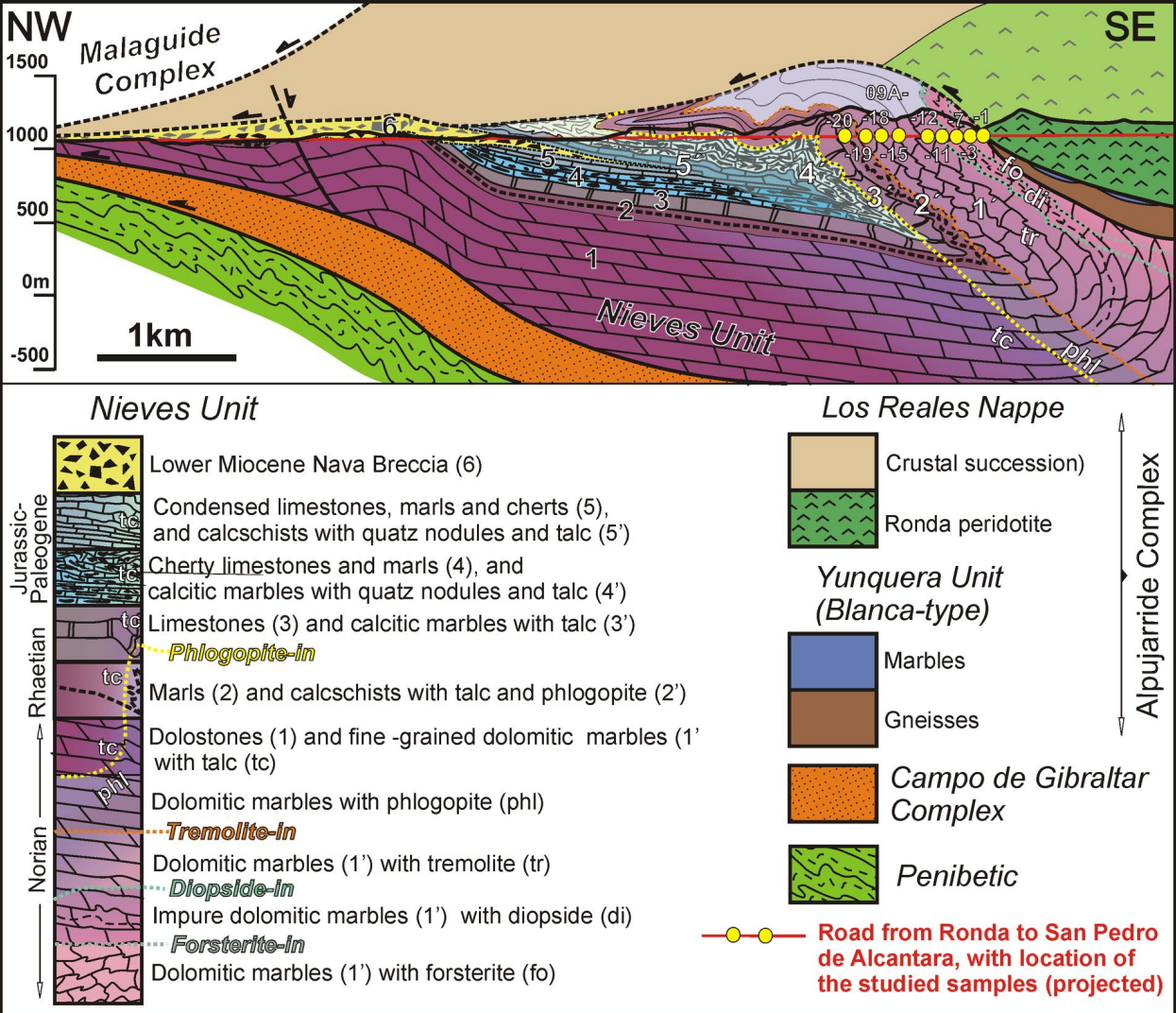


Nieves Unit

Ronda peridotites

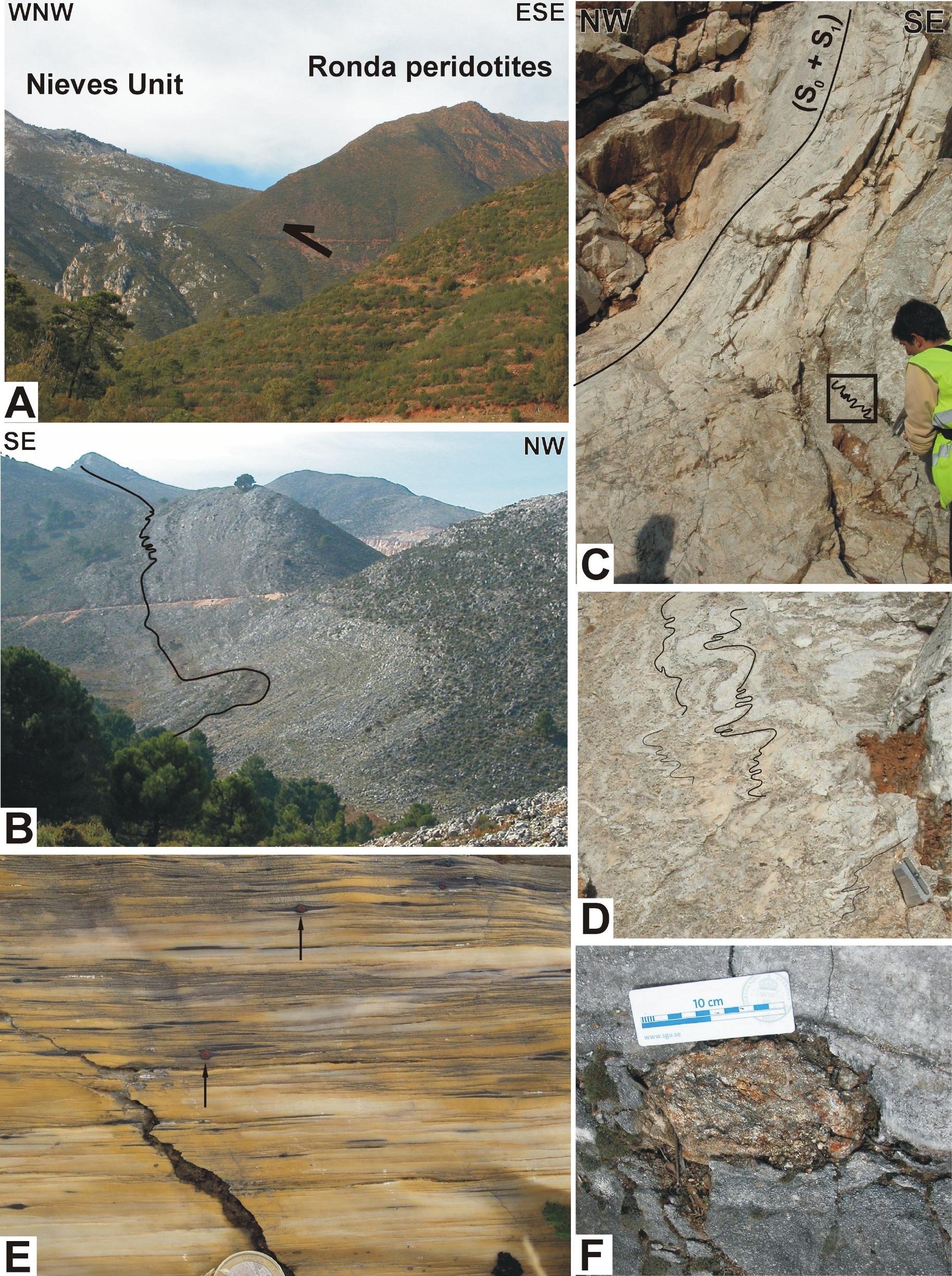

ESE NW

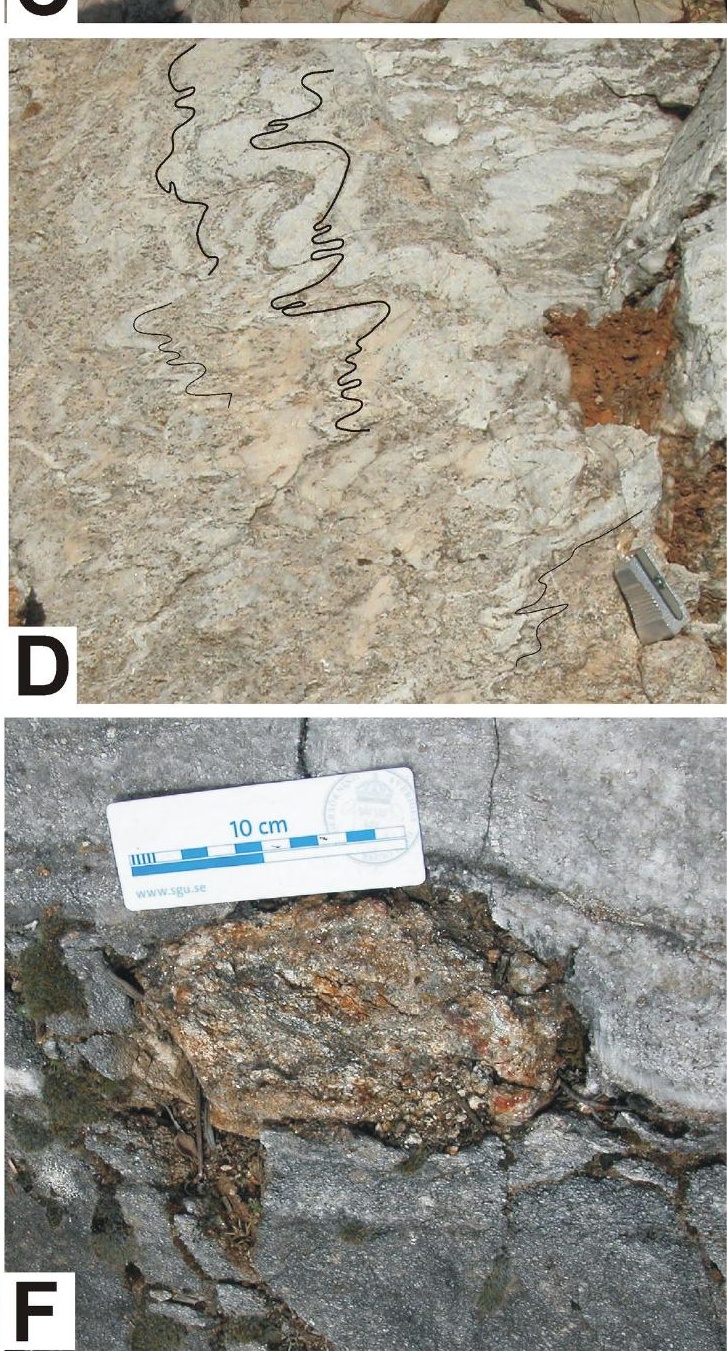




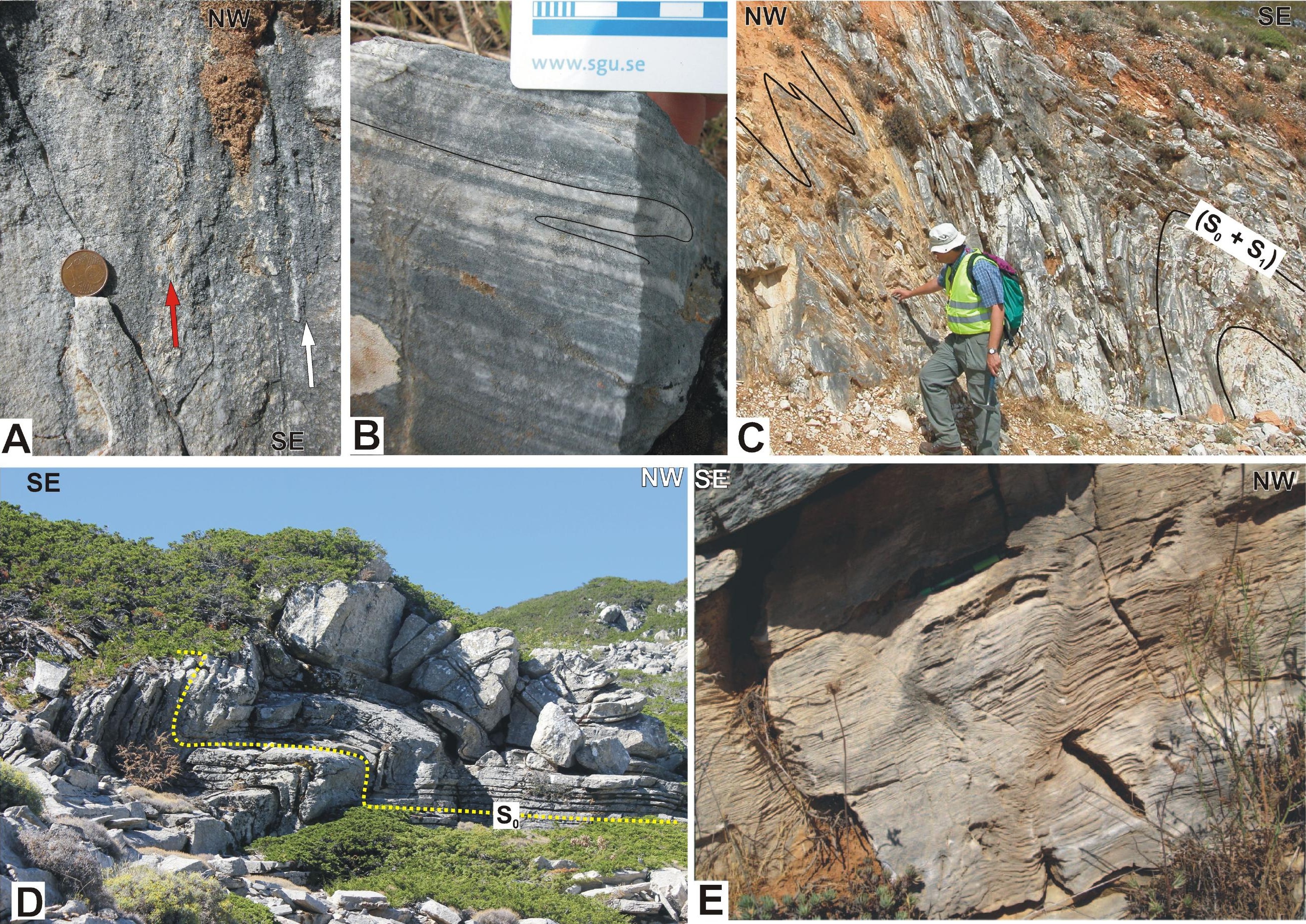



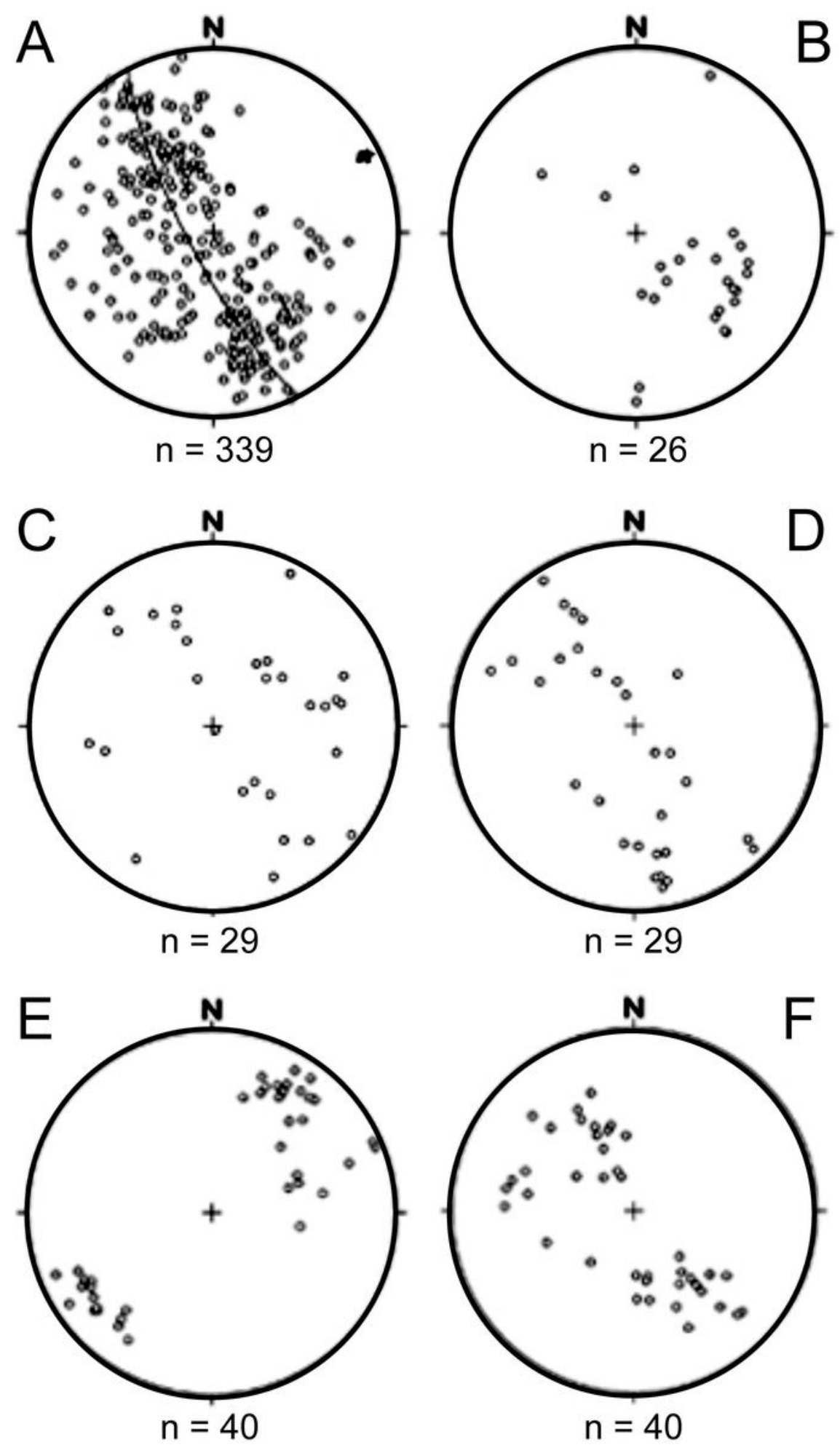


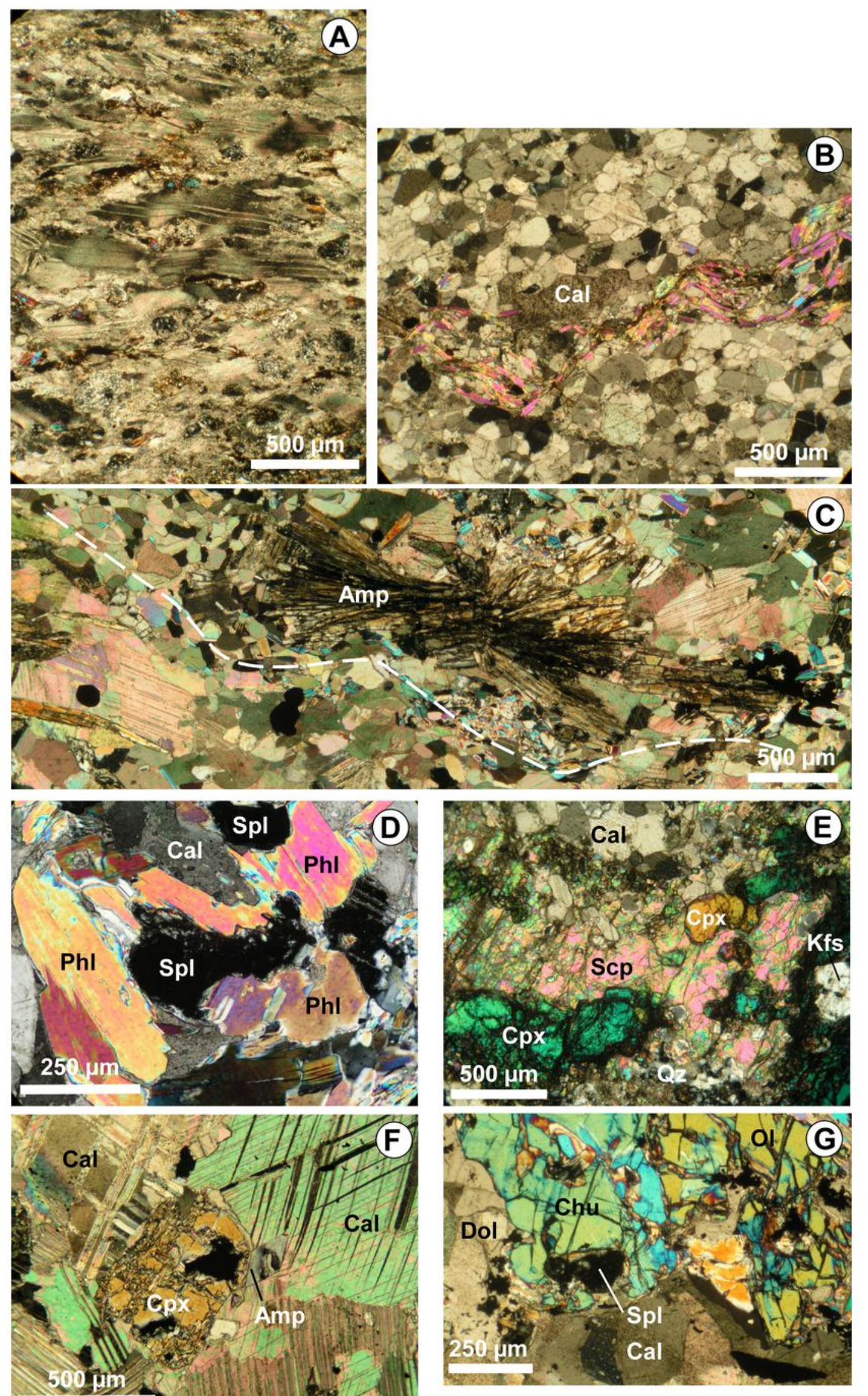




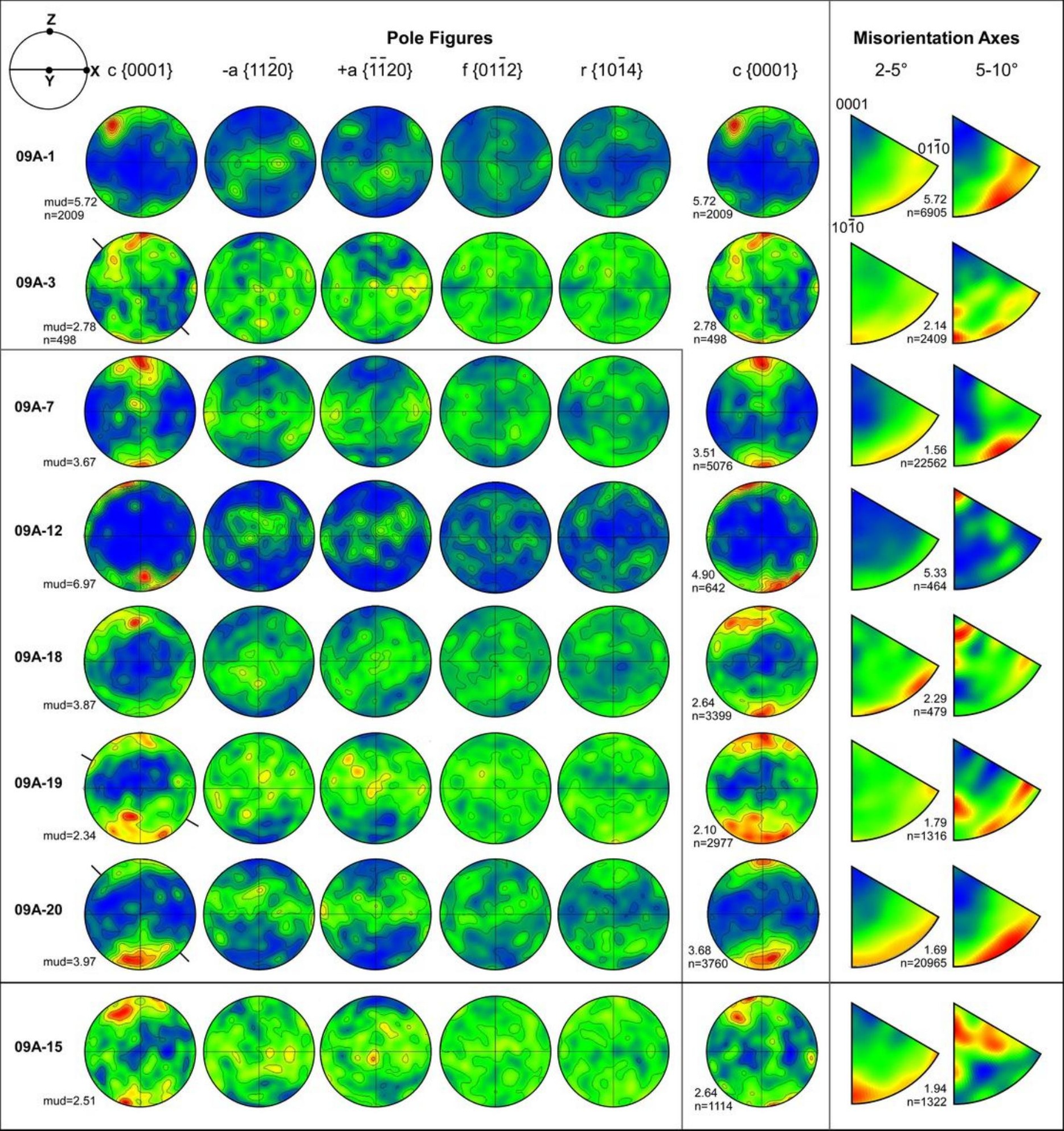

